\title{
THE LABOUR MARKET PARTICIPATION OF IMMIGRANT WOMEN: A STUDY ON IMMIGRANT WOMEN IN THE FLEMINGDON PARK AREA
}

by

Sew Ming Tian, B.Ed. Shiga University, 1997

A Major Research Paper

Presented to Ryerson University

in partial fulfillment of the requirements for the degree of

\author{
Master of Arts \\ in the program of \\ Immigration and Settlement Studies
}

Toronto, Ontario, Canada, 2010

(C) Sew Ming Tian 2010 
I hereby declare that I am the sole author of this major research paper.

I authorize Ryerson University to lend this paper to other institutions or individuals for the purpose of scholarly research.

I further authorize Ryerson University to reproduce this paper by photocopying or by other means, in total or in part, at the request of other institutions or individuals for the purpose of scholarly research. 


\title{
THE LABOUR MARKET PARTICIPATION OF IMMIGRANT WOMEN: A STUDY ON IMMIGRANT WOMEN IN THE FLEMINGDON PARK AREA
}

\author{
Sew Ming Tian \\ Master of Arts, 2010 \\ Immigration and Settlement Studies \\ Ryerson University \\ ABSTRACT
}

Through face-to-face interviews with seven immigrant women living in the Flemingdon Park area, this paper explores the barriers that immigrant women encounter in accessing the labour market, and the challenges they face in the labour market. The findings suggest that lack of work experience, language barriers, absence of networks, lack of education, and family responsibilities and gender roles are major barriers that immigrant women have to cope with while accessing the Canadian labour market. Working environment and underemployment appeared to be the challenges that immigrant women who are, or have been in the labour force, had to deal with in the work place.

Key words: Immigrant women, Flemingdon Park, barriers, labour market 


\section{ACKNOWLEDGEMENTS}

It is a pleasure to thank those who made this Major Research Paper possible. First of all, I am grateful to Flemingdon Family Daycare Services for their kind support in this research project. Also, thanks to the seven participants who have shared their valuable experiences with me. This project would not have been possible without their time and contributions.

Second, it is an honor for me to have Dr. Sedef Arat-Koç as my supervisor. I would like to thank her for her insightful comments and suggestions from the initial to the final stage of this research project. I would also like to thank my second reader, Dr. Grace-Edward Galabuzi for his constructive comments.

Last but not least, I would like to express my gratitude to my family and friends, especially to my husband and my two lovely children, Farhana and Fahad. Thank you for your support and prayers throughout the whole academic year. To my dear ISSers, thank you for such a wonderful year, I am so blessed to have you all in my life! 


\section{TABLE OF CONTENTS}

1. Introduction 1

1.1. Who Are Immigrant Women?

2. Literature Review: Immigrant Women and the Labour Market 5

2.1. Theoretical Framework 5

2.2. Barriers for Immigrant Women in the Labour Market 10

2.3. Neo-liberal Restructuring and Challenges in the Labour Market 23

3. Methodology 28

3.1. Approach and Worldview 28

3.2. Data Collection Tool $\quad 29$

3.3. Study Location $\quad 30$

3.4. Sample and Data Analysis $\quad 34$

4. Interview Findings and Discussion $\quad 38$

4.1. Barriers in Accessing the Labour Market 45

4.1.1. Lack of Work Experience 45

4.1.2. Language Barrier 47

4.1.3. Absence of networks $\quad 50$

4.1.4. Lack of Education 52

4.1.5. Family Responsibilities and Gender Roles 54

4.2. Challenges within the Work Place 59

4.2.1. Working Environment $\quad 59$

4.2.2. Underemployment 61

5. Recommendations and Conclusion 64

$\begin{array}{lc}\text { References } & 68\end{array}$

List of Appendix

A: Interview Questions $\quad 74$

List of Tables:

Table 1: Ethnic Origin of Flemingdon Park 32

Table 2: Categorization of Participants $\quad 42$

List of Figures:

Figures 1: Map of Toronto 33

Figures 2: Map of Flemingdon Park 33 


\section{INTRODUCTION}

"You have never worked in Canada before, have you?"; "Will you mind taking off your headscarf at work?"; "You should find a job with the airlines, as this kind of job offers better benefits and is good for women." These are questions and comments that I received while I was looking for employment after arriving in Canada. As an immigrant woman living in the country, I believe that my work search experiences are neither unique nor exceptional.

Integration is a process that most immigrants have to go through after arriving in Canada. Some researchers treat integration challenges of immigrants as universal, applying equally to men and women, whereas others stress that immigrant women have to deal with more barriers than men in the new society due to their gender (Miedema \& Tastsoglou, 2000). Murty (1998) explains that immigrant women take more time to integrate socially because of the cultural and linguistic barriers; and that they have to attend to their family's needs before they can do something for themselves. Immigrant women who are in the labour force usually have to shoulder a "double burden" because they are expected to play a traditional gender role as a mother and as a wife in the family other than their paid work (Boyd, 1984; Miedema \& Tastsoglou, 2000, p. 2).

The economic integration of immigrant women is challenging. Immigrant women encounter more barriers than men in accessing the labour market. In addition to the sexist stereotypes that women can only be employed in certain types of jobs, immigrant women also face the challenges to integrate into the new society. These restrictions have limited immigrant women's work opportunity, and relegated them to poorly-paid and insecure employment (Boyd, 1984; Cheng 1999). 
Studies explain that "gendered occupations" is a socially constructed phenomenon. I personally experienced this type of stereotypical perception in one of my job search experiences. When I was at a job interview for an administrative position, the interviewer did not go into the detail on the job responsibility; he also did not focus much on what I could contribute to the company if I were hired. Instead, he went on and told me about his wife's job as an airline staff and advised me to get a similar job as "it was good for women". Certain jobs are feminized because of the "unpaid domestic labour" that women perform at home. These responsibilities create an ideology that women are "naturally fit for nurturing, caring and secretarial roles in employment" (Cheng 1999, p. 47; Gabriel, 2004, p. 164). According to statistics, in $2001,46 \%$ of all immigrant women and $49 \%$ of Canadian born women participated in either administrative, clerical, sales or service positions. However, only $22 \%$ of immigrant men were employed in the same sectors. During the same period of time, $11 \%$ of all immigrant women were employed in manufacturing jobs, compared to only $4 \%$ of Canadian-born women who worked at the same sectors (Statistics Canada, 2006). The above statistical results indicate that more Canadian-born women than immigrant women worked in the administrative and service positions; whereas more immigrant women than Canadianborn women were occupied in manufacturing jobs. This implies that although in general, women are segregated in the feminized occupations, there are in fact differences among women as to who is more likely to occupy certain types of jobs. I would argue that compared to jobs in the manufacturing sector, administrative and certain service positions are considered as more privileged ones, and therefore, more Canadian-born women than immigrant women were represented in these sectors. 
Furthermore, immigrant women are also largely employed in part-time or short-term jobs. In 2001, of all working immigrant women aged between 25 and $64,47 \%$ were employed in jobs which had irregular working schedules. This figure is slightly higher than that of Canadian-born women of whom $45 \%$ were employed on a part-time basis (Statistic Canada, 2006). The study conducted by Tastoglou \& Preston (2005) states that immigrant women often face difficulty in maintaining their jobs after they join the labour force. Statistical results in 2001 show that $8.1 \%$ of immigrant women and $12.1 \%$ of recent immigrant women (arrived between 1990 and 2000) were unemployed. The rate for Canadian-born women was only $7.0 \%$, and for immigrant men it was $6.8 \%$ during the same period of time.

The above statistical figures provide some facts about immigrant women's performance in the Canadian labour force. However, the statistical results do not elucidate the reasons why immigrant women do not participate equally in the labour market. The research in this area is rather limited. The purpose of this paper is to contribute to the understanding of the nature and the causes of the labour market inequalities immigrant women face. This will be done through a focus on the labour market experience of immigrant women who live in the Flemingdon Park area in Toronto. In addition to discussing interview findings, I aim to make comparisons between my individual experiences and those of other immigrant women. As I have noted in the opening paragraph, as an immigrant woman myself, I have faced questions and comments that were irrelevant to the job requirement in my work search interviews. My path to employment was so difficult that I eventually gave up looking for a job. For this reason, I hope to discover the experience of other immigrant women to see whether there are similarities and differences between their experiences and mine. The main 
research questions of this paper are: 1) What are the barriers that immigrant women face in accessing the labour market? 2) What challenges do immigrant women face within the labour market?

\subsection{Who Are Immigrant Women?}

The term "immigrant women" refers to women who are permanent residents in Canada. They are legally entitled to most of the rights that a Canadian citizen enjoys $(\mathrm{Ng}$, 1996; Tastsoglou \& Miedema, 2005). Nevertheless, socially, as a result of the historical legacies of racialized and gendered treatment, as well as their present relationship to capitalist development, immigrant women are perceived as unskilled or low-skilled and unable to communicate well in English; and are therefore segregated in the lower positions in the labour market. Therefore, in popular use, "immigrant women" has been a socially constructed term that has had negative sexist, racist, and class connotations $(\mathrm{Ng}, 1996$; Tastsoglou \& Miedema, 2005). The term has been popularly selectively for racialized women. Whereas the term is not used for some European immigrant even if they are newcomers to Canada, racialized women would popularly be called "immigrant women" regardless of their length of stay in the country or even when they are born in Canada. The popular uses of the term also apply to people regardless of their legal status or immigration category. It is used not only for permanent residents but also those who come to Canada as temporary migrant workers or have undocumented status. In this paper, the term, "immigrant women" will be used to refer to women who migrated to Canada within the last 15 years under skilled immigrant, family reunification or refugee class. The women who are part of the research are 
legally allowed to reside and work in Canada. Women who are temporary residents and have no legal status in Canada are not included in this study. 


\section{LITERATURE REVIEW: IMMIGRANT WOMEN AND THE LABOUR MARKET}

\subsection{Theoretical Framework}

In order to understand the labour market participation of immigrant women, it is important to know that the labour market is largely influenced by the hierarchy of race, class, and gender. For example, historically in Canada, paid domestic work was carried out by workers from certain racial backgrounds such as descendants of formerly enslaved Africans, working-class Britons, and southern Europeans and Scandinavians. From the middle of the twentieth-century onwards, women from the Caribbean, Philippines and Eastern Europe have been over-represented in this occupation (Arat-Koç, 2006, p.196). Some women try to avoid domestic responsibilities by hiring other women (mostly from the less developed third world countries) to perform these duties (Arat-Koç, 2006, Cheng, 1999). This shows that class differences among women affect their gender status. Furthermore, women's paid labour that requires caring and cleaning skills are often associated with unpaid housework that they perform daily at home, leading to societal biases about these skills to be deemed unskilled (Gabriel, 2004). Based on the above insights, this paper will use labour market segmentation theory to discuss the labour market participation of immigrant women. Additionally, the paper will also draw on the human capital theory to explain whether or not the skills that immigrant women brought to the countries are beneficial to the economic development of the Canadian labour market, as well as immigrant women themselves.

According to human capital theory, an individual's investment in education is expected to be rewarded by better pay and conditions in the labour market (Gabriel, 2004); and the rewards are expected to at least make up for the costs that the individual has invested (Ashton \& Green, 1996). In the labour market, employers look for job seekers' human capital 
that best fits the job requirements; the candidates with more skills are paid higher wages (Salaff \& Greve, 2006). In addition, human capital theory expects that everyone should be able to choose education and employment according to his or her ability. If the person's earnings match the human capital that he or she possesses, then the market is in balance (Salaff \& Greve, 2006). When we look at the status and conditions of immigrant women in the Canadian labour force, we do not find much support for human capital theory.

Labour market segmentation theory provides some of the explanation for occupational segregation. Statistical discrimination theory is an economic theory that is related to labour market segmentation; it describes how some of the most prestigious and well-paid occupations are mainly held by males despite the fact that many women are more educated and have more skills than men (Anker, 1998). "Statistical discrimination" usually happens when the decision makers (in this case the employer) use "aggregate group characteristics" to assess the individual whom they deal with (Moro, n.d., p. 1). For example, people from a discriminated group (in this case women) are employed in lower paid and lower skilled jobs because the employers assume higher economic return from hiring a man. Partly, this is due to the historical tendency that men are more attached in the labour market than women (Moro \& Norman, 2003; Moro, n.d.). Another theory that is related to labour market segmentation is dual labour market theory (Anker, 1998). This is also the approach that I will take to explain the labour market participation of immigrant women in my paper.

Dual labour market theory is best known as labour market segmentation theory. The main argument of this theory is that the labour market is separated into a "primary" sector and a "secondary" sector (Anker, 1998, p. 20; Jenkins, 2004; Nativel, 2004; Yates \& Leach, 2007). The primary sector, which includes professional and managerial positions, offers a 
better job environment, high pay and a more secure employment to workers. Also, workers in this sector usually have opportunities for promotion. In contrast, the secondary sector contains jobs that are less desirable. The working condition in this sector is often poor and the wages are low. In addition, secondary sector workers have lesser chances for promotion (Anker, 1998; Hiebert, 1999; Jenkins, 2004; Nativel, 2004). It is argued that labour market segmentation is structurally integral to the logic and functioning of the capitalist economic system. Business owners are in favour of keeping discrimination because by creating differences between race and gender, they can create divisions among workers which will eventually benefit the owners economically (Peterson \& Lewis, 1999).

It is argued that while primary sector jobs are mostly filled by "white men", secondary sector jobs, especially those with low status ones, are often occupied by vulnerable group populations such as visible minorities ${ }^{1}$, women and disabled people. It is suggested that one of the reasons for women to be restricted in accessing the primary sector is because they are considered to have alternative roles such as homemaker and mother other than their paid jobs (Jenkins, 2004, p.6). Therefore, it is believed that women will be locked into insecure secondary work as long as there are either real or perceived changes in their domestic responsibilities. In addition to the disproportionate share of domestic labour they are burdened with, sexist assumptions, that women are not as capable as men, and that they cannot perform jobs that are as high level as men do, have also hampered their involvement in the primary sector.

\footnotetext{
'In the Employment Equity Act, visible minorities are defined as "persons other than aboriginal peoples, who are non-Caucasian in race or non-white in colour"; these include: "Chinese, South Asians, Blacks, Arabs and West Asians, Filipinos, Southeast Asians, Latin Americans, Japanese, Koreans, and Pacific Islanders" (Galabuzi, 2006, p. 92).
} 
Galabuzi (2004) points out that racialized groups (visible minorities) are often more likely to be ghettoized in the low-paying and low-skill sectors, especially racialized women and racialized immigrant women. Even though studies have found that these women actually have longer working hours than those of men; and that they shoulder more responsibilities and provide major financial support in the family, they are perceived as "less competent, less skilled, and less disciplined and as secondary wage earners" (Galabuzi, 2004, p. 193). Immigrant racialized women are found relegated in the following four sectors: processing and manufacturing, service sector in health and hospitality, clerical jobs, and domestic work. In addition to the fact that these women are marginalized in secondary sector jobs, they are also found working in precarious conditions such as contract and part-time jobs where their employers can exploit them by denying them proper wages and benefits (Galabuzi, 2004).

Some researchers point out that the division of the labour market is actually more complex than just a division between the primary and the secondary sectors (Fichtenbaum, 2006; Hiebert, 1999; Hirsch, 1980). For example, the primary sector can be again broken down into an "upper tier" and a "lower tier". The upper tier consists of white-collar and managerial level positions while the lower tier is made up of blue-collar workers (Hirsch, 1980 , p. 138). Also, hierarchy can be observed within a particular occupation due to an individual's racial status. Study has shown that in Canada, racialized nurses are treated unequally with white nurses. Compared to white nurses, they are often assigned harder jobs such as the heaviest physical jobs, patients with the most serious illnesses, and patients that are hard to deal with. They are also required to work in the worst or the least desirable shifts (Stasiulis \& Bakan, 2005). Due to the above reasons, Hiebert (1999) raises questions on the validity of labour market segmentation theory. He asserts that an appropriate theory that 
addresses the labour market should at least include the following considerations. First, the relation between employers and employees' views on an individual's human capital; second, discrimination due to individuals' ethnicity, gender, age, and so on; third, labour market sovereignty practiced by groups or individuals; and finally, individuals' geographical location.

\subsection{Barriers for Immigrant Women in the Labour Market}

Canada is one of the main immigrant receiving countries in the world. Since the nineteenth century, immigration has been important to Canada's demographic and economic development. The criteria on immigrant selection have been largely defined by immigration policy. From the 1950 s to the 1970 s, due to the increased manpower demands in the highlyskilled technical sectors, the government imported thousands of independent immigrants (both men and women) to fill these professional positions. In the meantime, there was also a high demand for labour in the garment and textile industries. Because these occupations were considered unskilled or semi-skilled, they were usually filled by women who entered the country as wives or relatives of the skilled immigrants under the "nominated" or "sponsored" class (Arnopoulos, 1979, p. 4; Boyd, 1984). For these reasons, during this period of time, immigrant women were found concentrated in either the highest or the lowest positions in the labour force. It is important to note however that although immigrant women were represented in professional sectors such as managerial and engineering positions, their numbers were not significant compared to immigrant men and Canadian-born women who occupied the same occupations. Many (nearly one-third) of them, especially those who did not speak either of the official languages, were over-represented in the poorly-paid sectors, 
including garment and textile industries, and service sector industries such as laundries, restaurants, and hotels (Arnopoulos, 1979; Boyd, 1984).

Even though there were actually more married immigrant women than married Canadian women participating in the labour force in the 1970 s, systemic studies on immigrant women's participation in the Canadian labour market were neglected (Arnopoulos, 1979). This was largely due to the fact that historically, the Canadian government considered immigrant men as the only source of immigrant manpower flow. The studies on immigrants' labour market performance also concentrated only on the experiences of immigrant men. Immigrant women were merely treated as dependants of the head of the household (immigrant men); their participation in the labour market was ignored, and their contribution to the economy was underestimated (Arnopoulos, 1979; Beach \& Worswick, 1993; Boyd, 1984).

In 1967 , due to the decline in the number of the immigrants from the traditional European source countries, the government of Canada decided to introduce the point system as a guideline to select immigrants based on their education, age, language and other factors such as occupation (Shan, 2009). Since then, Canada has been receiving economic immigrants $^{2}$ based on the point system. Economic immigrants are immigrants who are chosen under the point system on the basis of their educational background and skills; they are expected to make contributions to Canada's economy (CIC, 2009). Since the introduction of the point system, the source countries of immigration have changed. Immigrants from Asia (particularly from China and India) have increased drastically and later on have become

\footnotetext{
${ }^{2}$ Immigrants are admitted to Canada under three major categories: Family class, Economic immigrants and Refugees. Between 1996 and 2008, 55\% $65 \%$ of the total immigrants entered Canada under the economic immigrant category (CIC, 2009).
} 
the largest immigrant groups in Canada (Shan, 2009). Immigrants, especially recent immigrants, also appear to be more highly educated than Canadian-born populations. Recent studies also show that although most of the women still apply for immigration under family class $^{3}$ or as secondary applicants attached to their husbands' applications, many of these women are also well educated. Moreover, there is also an increase in the number of women who apply for immigration as the primary applicant (CIC, 2009; Shan, 2009; Tastsoglou \& Miedema, 2005).

Since the 1980s, there has been a significant growth in the number of immigrant women, particularly those with higher educational background and those from nontraditional source countries. Due to these reasons, more studies have been conducted to explain the labour market experiences of these women (Boyd, 1984; Mojab, 1999; Ng, 1990; Shan 2009; Sorensen, 1995; Tastsoglou \& Miedema, 2005; Tastsoglou \& Preston, 2006). The results reveal a contradictory picture. Despite the fact that immigrant women who have come to Canada in the past few decades are more educated than their previous counterparts, and have a higher educational background compared to Canadian-born women, they continue to face more barriers than Canadian-born women and immigrant men in accessing the Canadian labour force (Bauder, 2003; Grady, 2009; Human Resources and Skills Development Canada (HRSDC), 2007; Man, 2004; Tastsoglou \& Preston, 2006; Teelucksingh \& Galabuzi, 2007).

A study conducted on the highly educated immigrant women explains that despite their education and professional working experience in their home countries, these women were unable to enter into the "knowledge-based market". They remain unemployed or

\footnotetext{
${ }^{3}$ While economic immigrants are assessed based on their education and language skills, family class immigrants are exempted from such tests (Shamsuddin, 1997).
} 
underemployed in jobs that required "the use of their hands rather than their minds" (Mojab, 1999 , p. 123). Another study indicates that $20.9 \%$ of all immigrant women and $27.7 \%$ of recent immigrant women (arrived in Canada between 1996 and 2001) who are between the ages of 25 to 44 , hold a bachelor's degree. Nevertheless, only $17.3 \%$ of Canadian-born women who are in the same age group have the same educational background. The same study indicates that a significantly higher percentage of recent immigrant women (15.4\%) have obtained degrees higher than the bachelor's degree compared to the Canadian-born women (5.2\%) (Tastsoglou \& Preston, 2006).

As already mentioned, human capital theory assumes that individuals invest in training and education with the expectation that they will get a large financial return from what they paid for (Ashton \& Green, 1996). This theory clearly fails to explain the case of highly educated immigrant women's economic outcomes in the labour market. Statistics Canada (2006) explains that in 2000 , the difference between the average income of the group of all immigrant women and Canadian-born women was small. Immigrant women as a group earned $\$ 500$ less than what Canadian-born women earned $(\$ 34,500$ compared to $\$ 35,000)$. However, the earning disparity between the combined above populations and recent immigrant women (who arrived in Canada between 1991 and 2000) was large. As opposed to the average annual earnings of $\$ 34,500$ for immigrant women in general, recently arrived immigrant women only earned $\$ 28,000$ in the same period. Since studies have indicated that recent immigrant women are more educated than their previous cohorts, it can be concluded that recent immigrant women are not benefited by the human capital that they bring to the country. 
Statistics Canada (2006) shows that nativity (place of birth) is less a factor than gender to affect the earning of all populations. For example, the income that immigrant women had in 2000 was only $70 \%$ of what immigrant men earned. Similarly, Canadian-born women only earned $71 \%$ of what their male counterparts did. It is important to note that the above figures only explain the economic outcomes for people who were employed on a fulltime, full-year basis. Tastsoglou and Preston point out that full-time and full-year jobs are considered as "the most privileged segment" in the labour market (2006, p. 5). Their study shows that immigrant women who were in part-time or temporary jobs only earned $\$ 17,809$ in 2000 , compared to the earning of $\$ 18,736$ by Canadian-born women. In addition, race appears to be another factor that has had an impact on the earnings of immigrant women. Immigrant women who are from racialized backgrounds earn less than those who are not. In 2000 , immigrant women who were from visible minorities earned $\$ 20,024$, about $20 \%$ less than the amount non-racialized immigrant women earned $(\$ 24,990)$ (Tastsoglou \& Preston, 2006).

In response to the poor economic outcomes for immigrant women in the Canadian labour market, recent studies have been conducted to find out the challenges and difficulties that immigrants, including immigrant women and visible minorities encounter in the labour market (Buzdugan \& Halli, 2009; Miedema \& Tastsoglou, 2000; Reitz, 2001; Sorensen, 1995). The following sections will provide a brief overview of some of the factors that have been studied, for example lack of Canadian experience, lack of credential recognition, racism, language barrier, habitus and gender to explain their implication for the poor economic outcomes for immigrant women. 


\section{Lack of Canadian Working Experience}

Lacking Canadian working experience is one of the biggest challenges that immigrants, including immigrant women, have to face after arriving in Canada. Although a large number of immigrant women have years of working experience in their home country before coming to Canada, many of them find that their previous employment experiences are not valued by Canadian employers "as equal to or fitting what is known as Canadian experience" (Mojab, 1999; p. 126). The study conducted by Tastsoglou \& Miedema (2000) elaborate that the requirement of the so-called Canadian experience has become a "catch-22 situation" for professionals who are trained abroad (p. 223). A female participant in Man's (2004) study also addresses the same barrier. She states:

It's a catch-22. I cannot get a job because I don't have Canadian experience, and yet I don't see how I can possibly get Canadian experience without being hired in the first place!' (p. 141)

The lack of recognition for foreign gained experience has impeded immigrants' economic well being in the country. Buzdugan \& Halli (2009) argue that despite the fact that the work experience is considered one of the characteristics to measure a person's human capital; foreign gained experience did not increase their earning ability.

\section{Accreditation Problems}

In addition to the absence of Canadian work experience which acts as a barrier to finding jobs appropriate to one's skills and experience, immigrants find that their foreign credentials are also often not recognized in Canada (Bauder, 2003; Reitz, 2001). For example, a degree from India or Pakistan is not equivalent to the degree obtained from University of British Columbia (Bauder, 2003). One study shows that immigrants whose Bachelor Degrees 
obtained abroad are assessed as equivalent to Grade 10 in Canada and Master's are given the equivalence of Grade 12 under the Canadian system (Bauder, 2003). Immigrants often find that their professional credential is not recognized by trades and professions' licensing bodies, and because of this reason, many previously trained professionals are not able to practice their professions in Canada (Buzdugan \& Halli, 2009; Reitz, 2001).

Immigrant women and visible minorities are particularly affected by the devaluation of their credentials from abroad. Immigrant women are often required to re-train or reeducate themselves in order to improve their employment opportunity (Buzdugan \& Halli, 2009; Shan, 2009). However, because of the length and cost involved in the re-training process, not all immigrant women are able to do so. Especially for those who have children, their domestic responsibility places more restrictions on them to get re-training and reeducation (Man, 2004; Mojab, 1999).

In order to address problems related to accreditation and lack of Canadian work experience and help foreign trained professionals, in 2006, the government of Ontario enacted Fair Access to Regulated Professional Act. The Act has created an access center for individuals who are trained outside Ontario to get the information and network that they need to work in their own field; this includes: 1) a six-month internship opportunity in Ontario public service, 2) doubling the training positions for foreign trained medical graduates, 3) increasing language training and settlement programs and 4) new website "ontarioimmigration.ca" to help newcomers to Ontario. The Act has also created a Fair Registration Practices Commissioner to make sure that the regulatory bodies follow the legislation; fines will be levied to individual and corporation that fail to comply (Ontario.ca, 2009). Although the government claims that the legislation aims to ensure the licensing 
process is "fair, clear and open" (Ontario.ca, 2009, p.1), the Ontario Council of Agencies Serving Immigrants (OCASI) raises concerns about its applicability. OCASI criticizes that terms such as "transparent, objective, impartial and fair" (OCASI, 2006, p. 2) used in the Act are too ambiguous and need to be clearly defined (OCASI, 2006).

\section{Racial Discrimination}

Teelucksingh and Galabuzi (2007) point out that racial discrimination plays a significant role in the poor economic outcomes for individuals from racialized groups in the labour market. It is an added disadvantage for immigrant women who are visible minorities. As labour market segmentation theory suggests and studies demonstrate, racialized groups are over-represented in secondary sectors (highly precarious and low paying jobs) such as sewing machine operators, labourers in textile processing, taxi drivers and so on; while under-represented in the primary sectors (higher paid jobs) such as senior management and other professional jobs. Among immigrants, racial minority women are considered as the most vulnerable group because they face triple disadvantages as being women, immigrants and visible minorities (Galabuzi, 2006; Sorensen, 1995). As already mentioned, the study explains that in 2000 , foreign-born racialized women earned less than the amount of foreignborn women who are from a non-racialized background (Tastsoglou \& Preston, 2006). Teelucksingh and Galabuzi (2007) also conclude that the trend is going to increase over the years because of the increase in the racialized populations in the country. 


\section{Language Barrier}

Language is another factor that affected immigrant women's performance in the labour market. The knowledge of one or both of the official languages increases the rate of participation (Preston \& Giles, 2004). Statistics Canada (2006) indicates that in $2001,92 \%$ of all immigrant women above the age of 15 could speak one of the official languages. Based on Preston and Giles's study, it can be understood that these $92 \%$ of the immigrant women who speak either English or French, or both, have higher labour market participation than the others. However, it is important to note that although women who speak the official language(s) participate better in the labour market, their participation rates are still lower compared to Canadian-born women who have the same language skills (Preston \& Giles, 2004).

Although getting a language training program is a way to improve immigrant women's language proficiency and increase their competitiveness in the labour market, it is a challenging process. The stereotypical ideology that women are naturally fit for secondary sector jobs (such as caregiver and customer service) because of the priority they need to place on the domestic work that they perform at home, has impeded their access to the training program. This is largely due to the general assumption that there is no need for them to get anymore training because they are already doing the jobs that best suit them. Furthermore, the incomes that immigrant women bring home from these secondary sector jobs often provide financial support for the family even if they never are sufficient to make women themselves financially independent. Therefore, in order to continue supporting the family, they have to give up participating in the training program which eventually leaves 
them permanently in low paying and insecure secondary sector positions (Creese \& Kambere, 2002; Tastsoglou \& Preston, 2006).

Research indicates that even immigrant women who speak English fluently face language barriers in social and economic integration. This is mainly because they speak English with accents that are different than British and American. Studies have demonstrated that accented English poses a great disadvantage in the labour market participation and the earning of immigrant women (Creese \& Kambera, 2002; Tastsoglou \& Miedema, 2005). For example, one of the participants from Creese \& Kambere's focus group expresses her work search experience as follow:

What I also find is I made my resume and when they read it, it was excellent and then they called me for the job interview. When I started to answer some of the questions they asked, they said, "where are you from?" Then I said "from Africa." "When did you land as an immigrant?" Then I said "in Africa we also are trained in English." "No wonder, your accent is too heavy, we cannot understand you." (pp. 14-15).

Acknowledging accent to be one of the barriers faced by immigrant women in the labour market. Tastsoglou \& Miedema (2005) consider it as a form of "racism". They consider it to be a form of racism because accent is treated as a barrier not because it has a "functional problem", but because it is seen as "improper and inferior" (Tastsoglou \& Miedema, 2005, p. 214).

\section{Habitus}

In gaining access to the labour market, not knowing the "rules" of the Canadian labour market could also create obstacles for immigrant women. Extending Bourdieu's 
concept of habitus ${ }^{4}$, Bauder (2005) elaborates on how the foreign habitus that immigrants embody does not match the labour market rules of Canada. Habitus is defined as "a system of internalized structures, schemes of perception, conception and action common to all members of the same group or class constituting the precondition for all objectification and perception" (Girard \& Bauder, 2007, p. 38). It involves some of the group characteristics that are shared by a specific group or class. New members who do not understand these characteristics will be marginalized from the group. For example in Bauder's study, he found that a few women from former Yugoslavia were shocked and disappointed when they were asked about whether they had attended a six-months training program when they applied for a cleaning job. Because they had never heard of this kind of training in their home country, they could not understand the purpose of the course and had never thought that a course would be required for a cleaning job (Bauder, 2005). Similarly, while Canadian employers require all job seekers to submit a resume, some immigrants feel confused as they come from countries which do not have the same system. Some people even need to attend school to learn how to write one (Bauder, 2005).

For immigrants in technical professions, cultural differences also limit not just their access to the labour market but also equal treatment in the workplace. Qualified and experienced internationally trained engineers usually have good technical knowledge, but they are not familiar with the practices of non-technical skills in the labour market. These include "understanding of North American business practices", "bidding, tendering and contract administration", "observing dress code", and also "language skills" (Girard \& Bauder, 2007, pp. 47-48). Since this kind of non-technical knowledge is almost impossible

\footnotetext{
${ }^{4}$ See Bourdieu (1977)
} 
for immigrants to gain before coming to Canada, Ontario has required that in order for foreign trained engineers to be licensed in the province, they have to have at least one full year of working experience supervised by a licensed professional engineer in a Canadian jurisdiction. This is to ensure that immigrants will "fit" into the Canadian workplace (Girard \& Bauder, 2007, p. 45).

It should be noted that Bauder's research did not specifically discuss about how habitus affects the experience of immigrant men and women differently. Bauder does mention that family-class ${ }^{5}$ immigrants are more unfamiliar with the rules of the Canadian labour market. As the majority of family-class immigrants are women (CIC, 2009), it can be assumed that immigrant women face greater constraints than their male counterparts in finding a job in the Canadian labour market.

\section{Gender}

Gender is another important factor that is often mentioned to discuss the immigrant women's obstacles in integrating into the Canadian labour market. Findings by Statistics Canada (2006) as well as Shamsuddin's (1997) empirical study ${ }^{6}$ point out that gender discrimination plays a bigger role than birthplace in creating earning gaps. Man (2004) notes that within an immigrant family, traditionally males have been the principle applicants during the immigration application process ${ }^{7}$. This trend however, creates a negative image of the

\footnotetext{
${ }^{5}$ The research only examined the experience of immigrants from former Yugoslavia and South-Asia.

${ }^{6}$ Gender discrimination contributed to $63-70$ percent of the difference between a native-born male and a foreign-born female's mean log earnings; while birth place only had less than 15 percent effect (Shamsuddin, 1997)

${ }^{7}$ Before 1974 , married women were not allowed to apply for immigration as a principle applicant, no matter what their qualifications were (Arat-Koç, 1999).
} 
women in the household. They are often thought of as "not destined for the labour market" just simply because they have come to Canada as dependents (Man, 2004, p. 140).

The term "double-negative effect" has been used by several scholars to explain the poor labour market performance of immigrant women. The term explains that the labour market performance of immigrant women is negatively affected by the combined disadvantages of their country of origin and gender (Beach \& Worswick, 1993; Boyd, 1984; Shamsuddin, 1997; Sorensen, 1995). Studies have shown that immigrants in general encounter more obstacles than their Canadian-born counterparts in the labour market. In addition to the disadvantage as immigrants, immigrant women have to shoulder an extra burden as women. Boyd (1984) describes that the status of being a woman is perceived as an added weakness for immigrant women in two ways. First, the stereotyping of women restricts them to poorly-paid and insecure employment. Second, women are often expected to play a traditional role in the family. On top of their paid job, these combined responsibilities often create "double duty/double burden syndrome" for these women (Boyd, 1984, p. 1093).

In studies conducted to test the double-negative effect, some results support the concept of the double-negative effect, but others do not. For example, Boyd (1984) explains that the double-negative effect appears to be a factor in immigrant women's performance in the labour force. However, it does not apply to immigrant women as a whole. It is less significant for immigrant women who are from the United Kingdom and the United States ${ }^{8}$. This is probably because women from these countries do not encounter a language barrier as they speak English as their first language. Meanwhile, one of the findings in Beach \&

\footnotetext{
${ }^{8}$ However, Boyd (1984) did not separately discuss the experience between racialized and non-racialized immigrant women from these two countries.
} 
Worswick's (1993) research shows that the double-negative effect is only prominent among highly educated immigrant women. They then suggest that the non-recognition of their skills and foreign credentials might be responsible for these outcomes. This finding can be used to explain the reason why the income disparity between university educated immigrant women and their Canadian-born counterparts in 2005 was large (Grady, 2009) while the difference was small between immigrant women as a whole and Canadian-born women. Some research does not support the double-negative effect. Beach \& Worswick (1993) have found that immigrant women who worked in the secondary sectors actually have higher initial earnings than their Canadian-born counterparts. Beach \& Worswick (1993) explain that one of the possible reasons for this outcome is because immigrant women work harder upon arrival in order to support their husband's re-training program until their husband are able to support the family.

\subsection{Neo-liberal Restructuring and Challenges in the Labour Market}

Preston \& Giles (2004) explain that the average income gap between immigrants and the Canadian-born population has recently grown larger than it did in the past. Indeed, the earning capacities of recent immigrants who arrived in Canada in the 1990s are lower than those who arrived in the 1970s (Human Recourses and Skills Development Canada, 2007; Li, 2003). Human Recourses and Skills Development Canada (HRSDC) also highlighted that although immigrants who came to Canada in the 1970s might not have integrated into Canadian society economically in the initial stage, they usually caught up, or sometimes even went beyond their Canadian-born counterparts in the labour market. Immigrants who arrived in the 1990s have more difficulties attaining the earnings of Canadian-born populations. 
Although evidence shows that their initial earnings increased over time, no study indicates that they will eventually catch up to Canadian-born populations. They are also thought to be unlikely to catch up to the immigrants who came to Canada in the 1970s (HRSDC, 2007; Li, 2003).

In the previous sections, I discussed the barriers and challenges that have impeded immigrant women's participation in the labour market. It should be acknowledged that these barriers are not new. For example, research in the 1970s mentioned racism, sexism, and language barriers as the main factors behind the problems that immigrant women faced in the Canadian labour force (Arnopoulos, 1979). If barriers have remained the same, however, what needs to be investigated is why recent immigrants are predicted to be unlikely to catch up to the immigrants who came to Canada in the 1970s. More studies need to be conducted to examine this gap. I argue that the neo-liberal restructuring that began in the 1980 s and became well developed in the 1990s, is one of the main factors responsible for the poor economic integration of recent immigrants, in particular immigrant women.

Since the early 1980 s, due to the process of economic globalization, policies of restructuring have been significant shaping the Canadian state as well as economy (Arat-Koç, 1999; Man, 2004). The welfare state ${ }^{9}$ was replaced by a neo-liberal state with emphasis on the private over the public (Man, 2004). Government funding of social welfare programs, such as mothers' allowance, social housing projects and pensions for the elderly, have been reduced (Ilcan et al., 2007); government-subsidized child care or elderly care programs have been either cut back or privatized (Man, 2004; Zaman, 2007). Services in childcare,

\footnotetext{
${ }^{9}$ A welfare state is a nation where government is responsible for the basic needs of its citizens. This includes education, health services and sometimes, housing or housing subsidies. Its objectives are to balance economic growth and reduce economic inequities of the populations (Hyslop-Margison, 2006).
} 
healthcare, and elderly care have been either privatized in the family or transformed into commodified services in individual care and private homes (Zaman, 2007). Neoliberalism has involved the restructuring of social and political relations in society. Neoliberal ideology has criticized that government has been involved too much in the economy and society. It also argued that the welfare state has slowed down economic growth in the globalized economy. Neoliberalism has promoted a call for "personal responsibility and self-care" (llcan et al., 2007, p. 77).

Neo-liberal restructuring has significantly transformed the labour market. In the 1980 s and 1990s, there was a rapid growth in "non-standard employment relations" (NSER) ${ }^{10}$ such as part-time work, temporary work, flexible work, home-based work and insecure jobs. In the same period of time in Canada, the growth of the non-standard (secondary sector) employment was higher than that of full-time jobs, where only $33 \%$ of Canadian workers were recorded to have "normal jobs" (Ilcan et al. 2007, pp. 82-83; Man, 2002). As men are traditionally concentrated in standard forms (primary sector) of employment, it is the women, for example women with children, visible minority women and senior women, who are excluded from these standard jobs, and the situation is worse among immigrant women. As already described, reports show that immigrant women have the lowest participation rate in the labour market; they are also ghettoized in badly paid sales and production jobs (Man, 2002).

Economic and state restructuring has put women in a dilemma. As I have explained in the double-negative effect, on the one hand, women are encouraged to increase their labour

\footnotetext{
${ }^{10}$ NSER is also known as "flexible staffing arrangements, market-mediated arrangements, flexible working practices or more generally as atypical employment". The differences it has from standard employment is that the latter is usually connected to full-time jobs that are carried out at the employer's site under employer's instruction (Mitlacher, 2005, p. 371)
} 
market participation ${ }^{11}$ to help support family incomes. On the other hand, due to the weakening of public service, they are also expected to perform perhaps even more domestic duties at home (Ilcan et al., 2007). Man (2004) raises concerns about how neo-liberal restructuring has negative impacts on women's position in the labour market. She argues that deinstitutionalization of the child and elderly care put more burden on women as they are expected to shoulder those responsibilities "due to their gender" (p. 137). Specifically, Man's research focuses on deskilled Chinese immigrant women. She explains how the neo-liberal restructuring has had an impact on these women's lives in Canada. The majority of the Chinese immigrant women whom Man has interviewed were highly educated, but they encountered tremendous challenges while trying to access employment. Although some women managed to find jobs, most of them were segregated in the part-time and low status jobs which did not require a high level of qualification. At the same time, they also had to deal with housework and caring responsibilities at home. For those who had children, finding an affordable childcare was a big issue. Based on her research, Man criticizes the state for its failure to act on women's needs despite of the fact that childcare has long been a main concern for women $(2002,2004)$.

Structural changes in the labour market as well as the drastic reduction of social support programs have hindered immigrants', especially immigrant women's integration into Canada and led to their marginalization. Under these circumstances, many women are forced to work as "flexible and disposable labour" (Man, 2004, p. 137); they are also often treated as the "reserve labour force" (Cheng, 1999, p. 50). Usually, they are the first to be called to

\footnotetext{
"Before the 1970s, Canada advocated for "male bread-winner". Women were expected to stay home and perform domestic tasks. After the 1970s, with the emergence of gender equality, women were encouraged to participate in the labour market and reduce their financial dependency on men (Ilcan et al., 2007, p. 4).
} 
participate in the labour market whenever there are labour shortages in the market; they are also the first group to be sent home during the recession to perform domestic work (Cheng, 1999). 


\section{METHODOLOGY}

\subsection{Approach and Worldview}

This paper takes a qualitative approach to the study of the barriers and challenges facing immigrant women in the labour market. Creswell explains that qualitative research is "a means for exploring and understanding the meaning individuals or groups ascribe to a social or human problem" (2009, p. 4). Similarly, Holloway (1997) notes that qualitative approaches are used by researchers to "explore the behaviour, perspectives and experiences of the people they study" (p. 1). This methodological approach is ideal for my research because even though there is plenty of statistical information on the labour market, there is not enough qualitative research which helps with an understanding of the nature of individual experiences in accessing and surviving in the labour market in Canada.

My study is based on a social constructivist worldview ${ }^{12}$. According to Creswell $(2007,2009)$ social constructivists recognize that individuals have different opinions toward specific situations or things based on their own experience. Upon acknowledging the various interpretations that each individual make of the world that surrounds them, social constructivists then try to understand the multiple meanings of situations and experiences for individuals. Typically, among the four worldviews, social constructivism is seen as an approach that is associated with qualitative methodology. Creswell explains that a constructivist qualitative researcher gathers information from participants' views on a certain topic while the interpretations of the collected data are shaped by the researcher's personal experiences and backgrounds (2009). Participants in my study are expected to share with me

\footnotetext{
${ }^{12}$ Research is often designed based on researcher's philosophical worldview. There are four worldviews in research design: 1) The Postpositivist worldview, 2) The Social Constructivist worldview, 3) The Advocacy and Participatory worldview, and 4) The Pragmatic worldview (Creswell, 2009).
} 
their experiences in accessing the labour market. As an immigrant woman myself, I too, have experience in looking for employment after arriving in Canada. Therefore, my analysis of the data that I have collected is influenced by my personal experiences and background.

\subsection{Data Collection Tool}

Seven immigrant women were recruited from Flemingdon Park area to participate in individual face-to-face (or one-on-one) interviews. These interviews were used "to capture, in the participants' own words, their thoughts, perceptions, feelings and experiences" (Taylor, 2005 , p. 39). By having a chance to communicate with participants directly, and in a face-toface setting with semi-structured and open-ended questions (refer to Appendix B for the interview guide), I was able to look deeply into their experiences as well as hear their opinions and perspectives on the barriers and challenges that they face both in accessing the labour market, and in the labour market. In addition to the previously prepared interview questions, probes (Grewal et al., 2005) such as "Can you tell me more about that?", "Why do you think so?" were used to encourage participants to share more details of their experience. Interviews took between 30 and 60 minutes. They were conducted at places that were convenient to both the researcher and the participants. Interviews were audio recorded and notes were also taken. However, one of the interviews was conducted over the telephone because of the participant's job commitment ${ }^{13}$.

\footnotetext{
${ }^{13}$ The participant runs a home daycare business.
} 


\subsection{Study Location}

There are two major reasons for my decision to select Flemingdon Park as my study location. First, Flemingdon Park is one of the most multicultural neighbourhoods in Toronto. It is an area highly populated by recent immigrants. Because of its affordable housing, many new immigrants have chosen this area as their first home in Canada (Toronto Neighbourhood, n.d.). According to the 2006 census, approximately $67 \%$ of the populations who live in this area were immigrants (Statistics Canada, 2010).. There were also more than ten ethnicities living in this area, which include South Asian, Chinese, Latin American, black and also nonvisible minority groups. The 2006 census also shows that about $77 \%$ of the populations in Flemingdon Park were visible minorities (Table 1) (Statistics Canada, 2010).

The second reason for my selection of Flemingdon Park area as the site for my research is that, as a resident in the Flemingdon Park, I have, on many occasions, directly and indirectly heard women in this area talking about the challenges and obstacles that they face in looking for employment in Canada. Through this research, I intend to find out the experience of immigrant women in this area. I also hope that my findings will be useful for bringing awareness to society about the immigrant women's challenges in participating in the Canadian labour market.

Flemingdon Park is located at the north east of Toronto (Figure 1) within the borders of Don River E Branch, Don River W Branch, Eglinton Avenue East and Old Lawrence Avenue (Figure 2). The population in the Flemingdon Park in 2006 was 21,290 and women made up $52.2 \%(11,105)$ of the population (City of Toronto, 2007). Of all those who were 15 years and older $(16,685), 28.6 \%$ had a university degree or higher; which was slightly higher than the percentage of the same population group in the Toronto Census Metropolis Area 
(CMA) (26.7\%) (Statistics Canada, 2010). The median household income of the area in 2005 was $\$ 44,125$. This amount is significantly lower compared to the median income of Toronto CMA $(\$ 69,321)$, despite the fact that higher percentage of the population in the Flemingdon Park Area had a university degree (Statistics Canada, 2010). This is probably due to the fact that the majority of the population in this area are immigrants (recently immigrant in particular), and visible minorities. As already mentioned, recent studies have proven that recent immigrants and visible minorities face more challenges in the labour market compared to other groups of populations (Canadian-born, non-racialized population and previous immigrants), and they also have low economic outcomes (Oreopoulos, 2009; Teelucksingh \& Galabuzi, 2007). 
Table 1: Ethnic Origin of Flemingdon Park

\begin{tabular}{|c|c|c|}
\hline Ethnic Groun & Population & $\%$ \\
\hline South Asian & 7,490 & $35.21 \%$ \\
\hline Black & 2,170 & $10.20 \%$ \\
\hline Chinese & 1,915 & $9.00 \%$ \\
\hline Filipino & 1,510 & $7.10 \%$ \\
\hline West Asian & 1,365 & $6.42 \%$ \\
\hline Korean & 415 & $1.95 \%$ \\
\hline Arab & 405 & $1.90 \%$ \\
\hline Latin American & 370 & $1.74 \%$ \\
\hline Southeast Asian & 235 & $1.10 \%$ \\
\hline Japanese & 60 & $0.28 \%$ \\
\hline Visible Minority n.i.e.* & 145 & $0.68 \%$ \\
\hline Multiple Visible Minority** & 340 & $1.60 \%$ \\
\hline Total Visible Minority & 16,420 & $77.18 \%$ \\
\hline Non Visible Minority & 4,855 & $22.82 \%$ \\
\hline Total Population & 21,275 & $100.00 \%$ \\
\hline
\end{tabular}

Source: Statistic Canada (2010)

* 'n.i.e.' stands for 'not included elsewhere'. Includes people from Guyanese, West Indian, Kurd, Tibetan, Polynesian, Pacific Islander, and etc (Statistic Canada, 2010)

** Includes people who are from one visible minority group. e.g., Black and South Asian (Statistic Canada, 2010). 
Figure 1: Map of Toronto

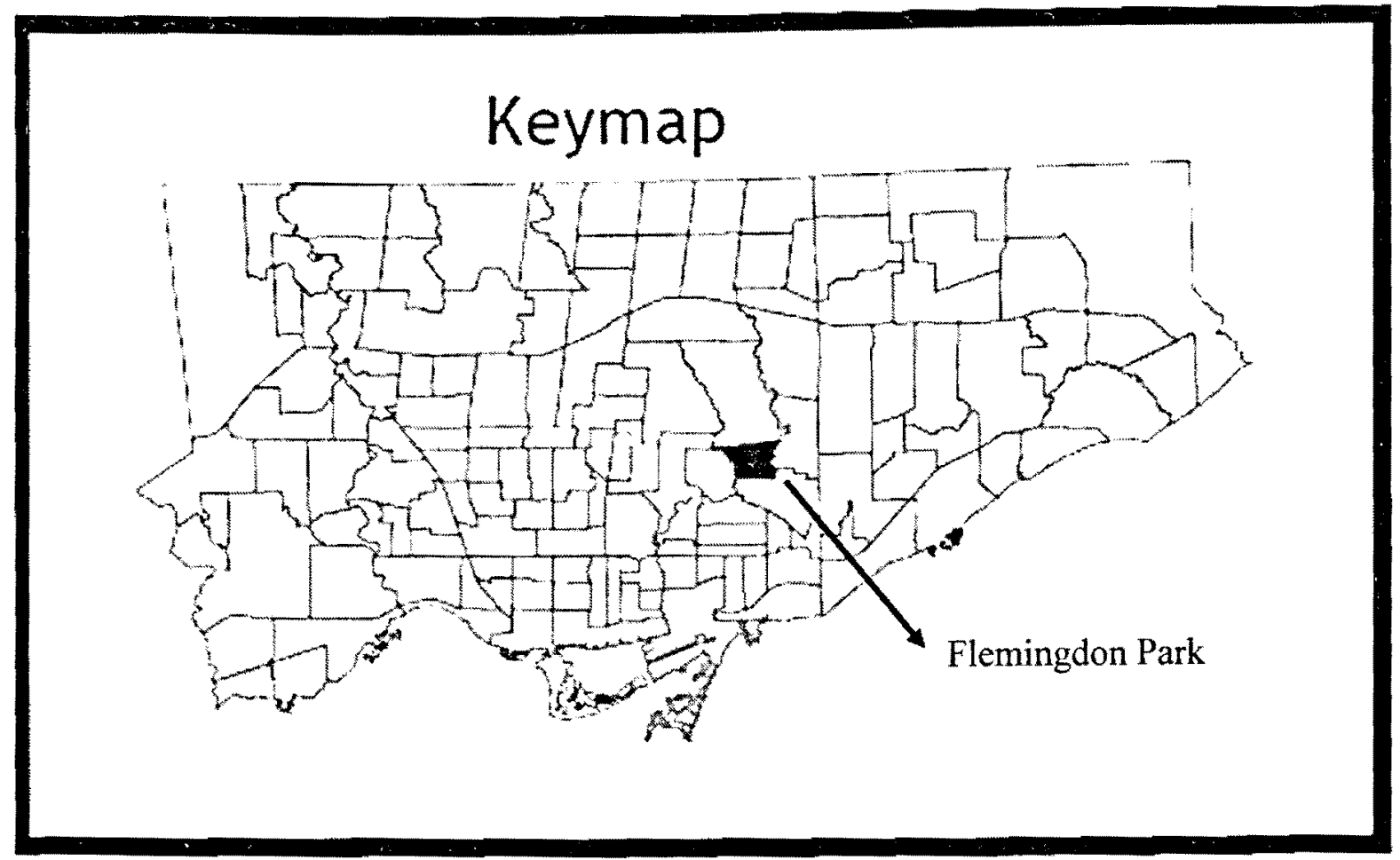

Source: Social Development, Finance and Administration Division: City of Toronto

Figure 2: Map of Flemingdon Park

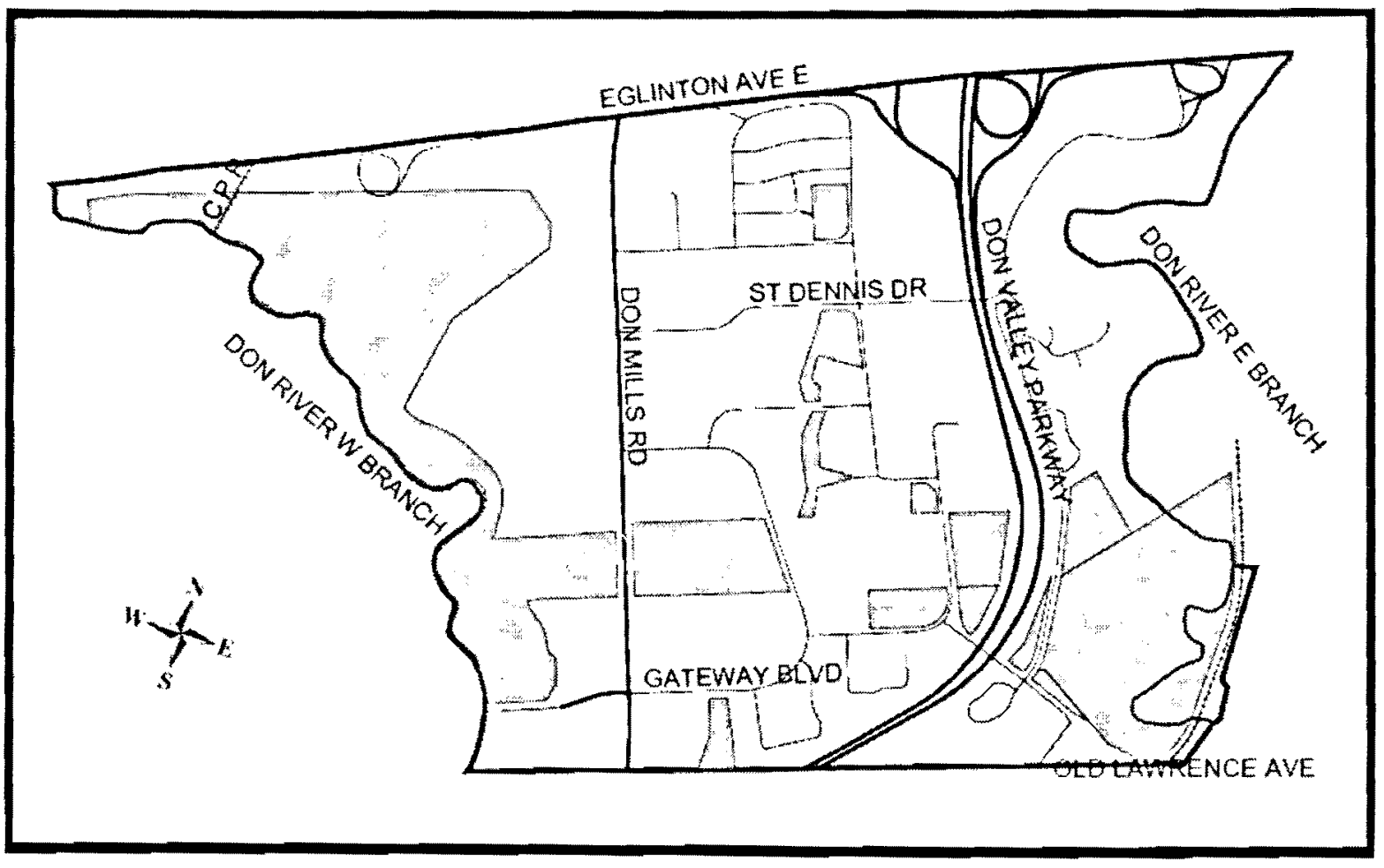

Source: Social Development, Finance and Administration Division: City of Toronto 


\subsection{Sample and Data Analysis}

Participants in my research were recruited in June and July 2010 through Flemingdon Family Daycare Services and my personal connections. Starting in mid-June, after I got my ethics application approved, I started attending the daycare centre's mother and children's drop-in program for 2-3 times a week, to look for potential participants. Before I approached the potential participants in the centre, the person-in-charge of the centre would briefly explain to them who I was and what I was trying to do in my research. This helped minimize the uncomfortable feelings that immigrant women in the centre might have had if they had been approached directly by me (a stranger). Among those who were qualified for an interview under the criteria used (which will be explained later in this section), ten women showed an interest in participating in my study. However, some of them could not commit to the interview schedule because they had to take care of their young children ${ }^{14}$. A few of them agreed to participate in the research, but did not show up at the scheduled time. Understanding their role as parents and also considering ethical issues (Creswell, 2009), I decided not to pursue them further.

In addition to the interviewees recruited through the daycare centre, I also approached some immigrant women through my personal connections. I contacted these participants by email or by phone, to explain them the research that I was conducting and asked for their consent before I interviewed them. Participants who were available for an interview within the limited time I had to carry out the research, were chosen to participate in the study.

\footnotetext{
${ }^{14}$ The mother and children's drop in program is for children from 0-6 years old. Therefore, all mothers who participated in the program have small children (infant, toddler).
} 
Through the above methods, eventually, seven women were recruited for the research: Four from a daycare centre (three of them were clients of the centre and one of them worked there as a volunteer) and three through personal connections. Originally, my plan was to recruit women from different community centres and organizations in the Flemingdon Park area, for example, library, immigrant service agencies in the area, and childcare centre, in order to increase the validity and generalizability of my findings. Unfortunately, the process of getting support from different community centres and organizations was a lot more challenging than I initially expected. I approached a few community centres and organizations in the area, to explain my study and ask whether I could get support (including permission in finding potential participants from the centre) from them. Eventually, only the Flemingdon Family Daycare Services (where I recruited four of the participants) agreed to support my research.

Creswell (2009) explains that as opposed to quantitative research which is based on random sampling and a large number of sites or participants, qualitative research emphasizes "purposefully select participants or sites" (p. 178). This emphasis helps the researcher to better focus on the research question and problem that he/she has raised or intended explore because only the individuals who have experience the central phenomenon will be selected to participate in the study. For example in my study, because my purpose is to explore the possible obstacles that hinder immigrant women's participation in the Canadian labour market, the participants in my study had to have some experiences in accessing the Canadian labour market. They also had to be residents of the Flemingdon Park area as I have indicated it as my study location. In addition to the above conditions, the participants had to be able to 
communicate in English since I was not able to provide any interpretation/translation service. Also, the participants had to fit into one of the following three categories:

1) Immigrant women who were in the labour force at the point when the research was being conducted.

2) Immigrant women who have never been able to work in Canada: women who have tried to access the labour market after landing in Canada, but whose attempts have been unsuccessful.

3) Immigrant women who were not working at the point when the research was being conducted: women who have worked in Canada previously after landing but stopped working for some reason.

Women who have never looked for a job in Canada or those who could not communicate in English were excluded from the study. It is important to mention that due to these restrictions; I had to reject a couple of women who worked as volunteers at the daycare centre. Their profiles did not fall into any of my three categories as they did not have any experience in looking for employment in Canada. Through conversation, I learnt that they had heard about the challenges/difficulties that immigrants (including themselves) would face in looking for a job if they did not have any Canadian working experiences, educational backgrounds, and language skills (they could communicate in English but not fluently). Understanding their own challenges, they did not plan to join the labour force right after they landed in Canada. Instead, they got involved in volunteer activities in order to get Canadian experience; in the meantime, they also attended the LINC (Language Instruction for Newcomer to Canada) program. They also told me that after their English reached a certain level, they would plan to enrol in college programs before starting to look for employment in the new country. 
According to Polit \& Beck (2008), the purpose of qualitative data analysis is "to organize, provide structure to, and elicit meaning from research data" (p. 507). In order to effectively uncover the data that I have collected, the following steps were taken to analyze the data. First, all interviews were transcribed word by word. As I have indicated in the ethics application, I personally did all the transcription myself. By repeatedly listening to the recorded interviews, I became very familiar with the data; not only with the words that were expressed by the participants, but also by the participants' non-verbal expressions such as laughter and pauses throughout the interview. Second, I carefully read through the interview scripts over and over again to identify themes that were connected to my research questions. As well, codes were created according to the themes. Third, literature and transcripts were reviewed simultaneously to identify any similarity/difference between the previously conducted studies and the research findings. 


\section{FINDINGS AND DISCUSSION}

Seven immigrant women were recruited in the study in order to explore the barriers that immigrant women face in accessing the labour market, and the challenges that they face in the labour market. It should be noted that although I had imposed the restriction that participants in my study had to have experience in accessing the labour market in Canada, and that they had to fall into one of the three categories that I have defined in my study, I did not intentionally select participants based on their birth place and ethnicity. Coincidentally, among the seven participants, six of them were originally from South Asia (three were from Sri-Lanka, two were from Bangladesh, and one was from Pakistan) and another one was from Mainland China. All immigrant women participating in the study had children. This was partly because some of the women were recruited from a daycare centre. Women who joined the program in the childcare centre all had small child/children. The women recruited through my personal connections also happened to have children. Due to the above reasons, and also because of the geographically defined research area, it is important to mention that the findings of the study cannot represent the experience of immigrant women as a whole. Even though the findings of this research may not be generalizable to all immigrant women in Canada, it is hoped that this small scale research might raise awareness of future researchers on the issues that immigrant women are facing, so that larger scale research projects with more holistic analyses might available in the future.

Due to ethical considerations, the participants' real names will not be disclosed. Instead, they will be referred to as Participant $1,2,3$ and so on, depending on the category they belong to according to their labour market experiences. Participants 1,2 , and 3 are women who had worked in Canada after their arrival. They stopped working for different 
reasons and were not working when the study was being conducted. Participant 4 had never worked in Canada. She had tried to look for a job but her attempts were unsuccessful. Participants 5, 6 and 7 were working when the study was being conducted. It should be noted that none of the participants was working in the positions where they were first employed after they arrived in Canada. In the following section, I will give a brief introduction on all women who have participated in my study (Table 1). It should be noted that because of the nature of the survey and for reasons of confidentiality, the actual age of the participants will not be revealed; instead, it will be referred to in a range of years.

Participant 1 is originally from Bangladesh and she is between the ages of 31 and 40 . She landed in Canada under the Family Class category and has lived in Canada for about 510 years. She obtained her Master's Degree in Statistics back in Bangladesh. Before coming to Canada, she worked in an advertising agency as a copywriter. In Canada, she had experience working as an exam invigilator and a payroll accountant. She also spent five years in Canada obtaining a payroll certification. She is a mother of two and is currently not working. She is also not planning to look for employment in the near future (until her younger daughter starts full-time school).

Participant 2 was born in Pakistan and she is between the ages of 31 and 40 . She came to Canada about 5-10 years ago under the Family Class category. She finished her university degree (Bachelor) in Pakistan and worked as a Sales Engineer before coming to Canada. In Canada, she was employed in various part-time positions in customer service and sales industries; and had also assisted her husband's business. Currently, she is not working but was expecting to start a job three days after the interview, as a customer service staff. She has two school age children. 
Participant 3 immigrated to Canada from Bangladesh as an Independent Class immigrant. She is between the ages of 31 and 40 and has lived in Canada for 5-10 years. She has a Master's Degree in Economics which she obtained in Bangladesh. In Canada, she attended the LINC program and was asked to work as a LINC outreach worker upon the completion of the course. She worked in the position for six months before moving to another area in the city. She also attended the Childcare program and the Customer Service program. She is not currently in the labour force but is enthusiastically involved in voluntary activities in the local school. Her dream is to work in a school environment. She hopes that her voluntary experience will gain her a position as a staff (e.g. lunch room supervisor, or educational assistant) of the Toronto District School Board (TDSB) one day. Participant 3 also has two school age children.

Participant 4 is originally from Sri Lanka. She immigrated to Canada less than 5 years ago under the Family Class category. She is between the ages of 18-30. She finished her high school and worked as a kindergarten teacher in her home country. However, she has never worked in Canada. She had tried very hard to find a job after landing in Canada, but was unsuccessful. She is currently a student in an English as a Second Language (ESL) program which she has been attending for more than a year. She also volunteers at the local daycare centre where I recruited the interview participants. She is hopeful that she will be admitted to a childcare course after her proficiency in English reaches a higher level. Eventually, she wishes to get a job in a daycare centre. Participant 4 is a mother of two.

Participant 5 immigrated to Canada from China under the Independent Class category. She is between the ages of 31 and 40 and has lived in Canada for about 5-10 years. She attended university in China and was a medical doctor before arriving in Canada. After 
landing in Canada, she was employed by an employment agency working as a general labourer in a factory on an on-call basis. She then decided to join a two-year nursing program. Upon completion of her course, she started working as a nurse. She is currently employed by three different employers and is working in three different locations (nursing home, hospital and retirement home). It should be noted that all these three jobs are on a part-time and oncall basis. She is also eagerly looking for a permanent position which she said will provide her a safer income for her family and her two children.

Participant 6 arrived in Canada from Sri Lanka as a refugee 10-15 years ago. She is between 41 and 50 years old and had finished high school in her home country. She worked as a kindergarten teacher before coming to Canada. In Canada, she enrolled in a high school program and worked in a bank after completing Grade 12 . She is currently running a home daycare business. However, her final career goal is to find a job in an office environment. Participant 6 has three young children.

Participant 7 is an immigrant woman from Sri Lanka. She is between the ages of 31 and 40. She was sponsored to Canada under the Family Class category soon after she finished her high school, around 10-15 years ago. Therefore, she had never worked before coming to Canada. After arriving in Canada, Participant 7 was keenly looking for employment. First, she volunteered at an Islamic school and hoped to get a position in the same place but was unsuccessful. She then took an interior design (window treatment) course and started running a home-based curtain business but it also did not work out well. Finally, she enrolled in a full time childcare course and started a home childcare business three years ago, which she said is the best solution for her at the moment. Her dream is to become a school teacher in the future. 
Table 2: Categorization of Participants

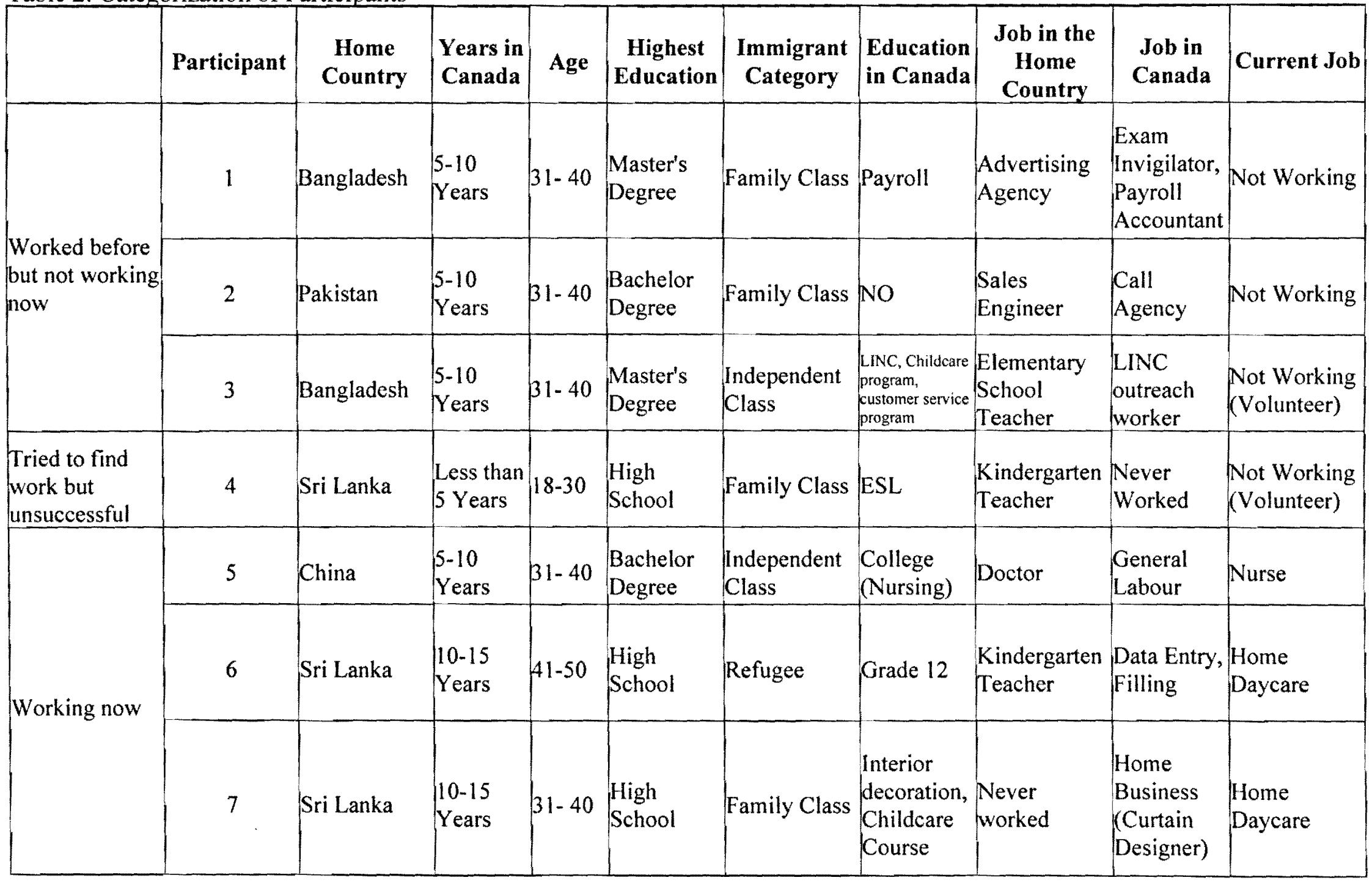


The information from the interviewees suggest that the major barriers that immigrant women face in accessing the labour market include, but are not limited to: lack of work experience, language barrier, absence of networks, lack of formal education, and family responsibilities and gender roles. For those who are, or had been in the labour force, working environment and underemployment appear to be the challenges that immigrant women have to deal with in the work place. In addition, the significant gap I discover between the literature and my research is the fact that even though all seven participants were from visible minority groups, none of the women mentioned race as factor in the barriers or challenges they faced. This does not mean, however, that the participants in the study have not faced any racial discrimination in their labour market experiences. The reason for the absence of emphasis on racism as one of the barriers might be based on the fact that "race" is obvious to people as a factor only when there are clearly, openly expressed racist ideas. It is important to remember, however, that race works also in subtle (such as in relation to the bias about certain accents, already raised in the literature and in my research findings) and structural ways, even though it may not be expressed verbally.

Before I begin to elaborate on the above research outcomes, it should be noted that despite all obstacles and challenges that participants in the study have pointed out, majority of them (five out of seven) were very optimistic about their future career opportunities. In the interview, I asked them to describe their dream jobs and then I questioned whether they thought it was possible for them to achieve their goals. Four (Participants 2, 4, 6 and 7) out of seven participants gave me a positive answer. Some of them even had a plan in mind for achieving their so-called "dream job". Participant 3 said "yes", if she did not give up trying. Participant 1 thought it was unlikely for the short-term, as she did not see that she could 
overcome the barriers in the near future. Finally, Participant 5's answer was mixed. On the one hand, she said that she had no dream job, and she had given up being a doctor here in Canada. The reason that she chose to be a nurse in Canada was simply because she needed to make a living. On the other hand, she wanted every immigrant woman to stay positive and keep trying for her dream job. Although she mentioned that she had no dream job in Canada, she was confident that she would get a better job in the future. She looked forward to finding a permanent full time position as a nurse to replace her current three part-time nursing jobs. Therefore, overall, the study suggests that despite all the obstacles, immigrant women believe that they will successfully overcome barriers if they are determined to do so.

Another important finding suggests that although more than half of the research participants had obtained a Bachelor degree or higher in a post-secondary institution, none of them was employed in the more privileged sectors of the labour market traditionally dominated by males. As I have explained through the dual labour market theory, while primary sectors tend to employ white and male staff, secondary sectors are mostly filled with women, visible minorities and disabled people (Jenkins, 2004; Gupta, 1996). The study confirmed that immigrant women from visible minority groups are frequently found segregated in the "peripheral" (Gupta, 1996, p. 6) sectors where their human capital is underutilized. 


\subsection{Barriers in Accessing the Labour Market}

\section{I.I. Lack of Work Experience}

Previously conducted studies (Man, 2004; Tastsoglou \& Miedema, 2005; Mojab, 1999) point out that lacking Canadian experience appears to be one of the main barriers that immigrant women face in accessing the labour market. In my research, I found that the women in the study lack not only Canadian experience. Many of them did not even have any working experience in the field that they want to work at; some did not have any work experience before coming to Canada; and others tried to look for employment in other than their original occupations. Therefore, for those in my research sample, instead of lacking Canadian experience, lacking work experience in general would better describe the barrier.

Participant 4 felt upset when she was asked for experience when she applied for jobs in places like a factory and a department store. She looked really disappointed when she expressed her experience:

I applied for any job, that time one year, no, six months after I came, they [the employers] asked for experience. Every job I applied, they asked for one and a half year, two years experience. So that time I could not apply for the job. (Participant 4)

In the end, she gave up looking for a job and started volunteering in order to get the work experience. Participant 4's experiences are similar to mine. I was asked for Canadian experience when I applied for jobs in Canada. Because I realized that would not be able to get employed before getting Canadian experience, I started volunteering at a non-profit organization which I hoped would provide me with relevant experience.

Participant 1 had worked before coming to Canada, and she also speaks English fluently. However, because she changed her field of expertise after coming to Canada, she 
did not have any relevant experience in the new field, despite the fact that her new profession (payroll accountant) was certified in Canada. She described the efforts she had made in order to get a position as a payroll accountant:

In order to achieve that work, first I had to finish my certification here. Then I would start to look for a job, but I didn't get any call or any answer for my application...I was looking for a job very actively... most of the area I was looking for, they asked for Canadian experience first. So that was vey important barrier, I had very good marks, but they didn't count (Participant 1)

She then explained that the economic downturn during the time when she was looking for employment had made the market more competitive. Many experienced people were laid off at that time and were also looking for jobs, so people who had no work experience like herself were "hard to fit in". Eventually, Participant 1 was referred by a neighbourhood settlement agency to a government-funded three-month work search program where she gained the relevant work experience. She successfully found a job before the program ended. However, she quit the job three weeks after she was employed due to the poor working environment (which will be explained in the later section). When I asked her about her future career options, she replied that she planned to rejoin the labour force two-three years later, after her younger child starts full-time school. She also said that she has foreseen that she will face the so-called "experience" barrier again when she is ready to re-enter the work force, due to the gap between her last work experience and the time when she is ready to reintegrate into the labour market.

Job search experiences of Participants 3 and 6 provide an insight into this concern of Participant 1. Participants 3 and 6 had both worked after coming to Canada. However, after their first occupation, they had a few years' gap before they started looking for another position. When I asked them to describe their job search experiences in the second round, 
they both asserted that their previous experience had not benefited them at all in finding a new job. Participant 3 explained that although she had sent out 20-30 resumes in the past year, only one school called her for an interview. Moreover, she thinks that it was not her previous work experience, but her current active involvement in the school voluntary activities that got her the chance for the interview.

Participant 6 had a similar experience. When she tried to look for a job in her previous field (data entry and filing) a few years ago, she found that the situation was different from the time when she first got the job. She described her first work search experience back in 1997 and 1998 as "easy"; "many people called me for interviews" she said. She then added "if I sent [the resume] in the morning, evening I got the message, they had job available, then interview". On the other hand, she used "very difficult" to describe her second job search experience. She said that she had sent out many resumes but that in spite of her previous experience, she could not even get a chance for an interview.

It can be concluded that although having (Canadian) work experience is considered one of the key factors to secure a work position, it does not necessarily mean that any job experience directly guarantees successful employment. When the experience is gained, and also how relevant it is for the position that the candidates are looking for, are all factors that affect employers' decisions.

\subsubsection{Language Barrier}

Boyd (2009) argues that immigrants' economic integration and well-being are closely related to their ability to handle the official language(s) in Canada. She cites previous 
research which has shown that immigrants who had a lower level of language proficiency also had a lower rate of labour market participation. A recent report conducted by the Toronto Immigrant Employment Data Initiative (TIEDI) (Tufts et al., 2010) indicates that the better the language skills an immigrant possesses, the higher average hourly wages he/she earns.

As language has been one of the interview recruitment criteria for my research, all participants in the study were able to communicate in English. Nonetheless, regardless of their language ability, some of them still faced language as one of the biggest barriers in integrating in the Canadian work place. This finding is somewhat different from my personal experience. Although English is my third language, and I speak English with an accent other than British and American, I did not feel that language was a factor in impeding my access to the labour market. Among the participants, Participant 4 faced a greater language barrier because she had very limited English proficiency when she first came to Canada. Eventually, she stopped looking for employment and started volunteering. She hoped that her volunteer experience would not only provide her with some work experience, but also that it would help improve her English proficiency. In addition, she also enrolled in an ESL course where she could practice English daily. She recalled her experience by stating:

Our country is not English, I came here is big problem for me the language, I went everywhere to apply for job, everybody asking me for English, they wanted is for fluently, that was problem for me. That time I felt very sad, that's problem for me...That time I stopped look for work, after I tried to go to school (ESL course).(Participant 4)

At the time of the interview, Participant 4 had no problem in her comprehension of English. She is also a confident and effective communicator. However, she still finds that language is 
a great challenge for her. When I asked her whether she was thinking of looking for a job again, she replied:

Yeah, now I am trying but I cannot find, because I speaking English no one understand, because speaking accent. In the school, when I speak to teacher, teacher doesn't understand, because I just think I have accent, I don't know how to say that. (Participant 4)

Apart from their personal experiences, all participants in the study were also asked to express their opinions on the barriers that immigrant women in general face while accessing the labour market in Canada. In response to this question, six out of seven participants noted "language" as one of the major barriers, including those who have high proficiency in English. A surprising, or rather shocking finding emerging from this question is Participant 2 explaining how she herself has a bias against people who speak English with accent (other than British or American), to explain why accented English is considered as a barrier for immigrant women. She first described her opinion when I asked her in what sense did she think that language was a problem:

You know like the accent is different...back home you speak English differently, now it's a new environment...like some people do speak very good English, but some people, they do speak English, but you know it's like, the accents are not good enough. (Participant 2)

She then continues to share with me her own thoughts:

If I call Bell Canada [a communications company], sometimes the call goes to India, so you catch from the accent that they are from India, so I don't talk seriously to them. I know that they don't know much. (Participant 2)

To conclude her opinion, she stated that an immigrant woman is treated differently depending on how "good" the English she speaks; if she speaks good English, she will be treated (by Canadians) as "one of them"; otherwise, she will be seen as an outsider. 
Participant 2's comment on the accented English confirms the statement made by Tastsoglou \& Miedema (2005) that the real barrier of the accent is not the "sound" itself. Even though "soundwise", many accents from the U.K. or the U.S. may be more challenging to comprehend, people from these two countries are still likely to enjoy social respectability because of their national origins. The attention paid to the national background of the person speaking the "accent" rather than the actual accessibility of their speech means that it is rather whether the accent is treated as "improper and inferior" that creates the real obstacle (Tastoglou \& Miedema, 2005, p. 214). In fact, it can be argued that "language", in this case, is not simply a communication tool. Instead, it is used to determine the quality of a person's human capital depending on the accent he or she speaks. Certain accents are perceived as white, and as signs of sophistication, making their use a privilege and a symbol of power while other accents are devalued and marginalized. Due to this accent-based discrimination, most immigrants who speak English as their second or third language, especially those who come from Third World backgrounds, may anticipate facing more difficulties in the labour market integration.

\subsubsection{Absence of Networks}

Before explaining how absence of networks is seen as a barrier for immigrant women to integrate into the labour market, I will first highlight how networking had helped Participants 1, 3, and 5 in getting employment. It should be noted that among them, Participants 1 and 3 had no relevant experience prior to the positions.

Participant 1 first worked as an exam invigilator at York University. While talking about her work search process, she mentioned that she had actually no plan to work at that 
time. However, a friend of hers who was working at the University told her about the recruitment opportunity and asked her to give it a try. So she went and dropped her resume and she got called from the University "right away". Participant 3's first job as a LINC outreach worker was offered to her by one of the LINC teachers after she completed her course. Since she did not actually "search" for this job, she was puzzled when I asked her to describe whether her background (education and previous work experience) had helped her when she looked for the job.

Participant 5 is employed as a nurse by three different facilities. She explained that she got her first and second position because she had a "network". The first one was a Chinese nursing home. "Even if it is very far, but it's easier to get in", she recalled. Her second position is where she had her pre-graduate (practicum) when she was a student in a nursing program. She shared with me the experience she encountered when she sent in her resume:

The second job where I do my pre-graduate, I sent my resume and saw a pile of resume there, a pile of resume (emphasis). So you know, I can't imagine, if you are (a human resource person) which one you will hire, you should hire the familiar one. So I think network in really really important... They know me, so I got the job. The network is really important. (Participant 5)

Participant 5 compared this experience with the challenges that she faced, due to lack of networks, when she first arrived in Canada. Because of absence of networks then, she felt that she faced more obstacles finding a general manual job right after she landed in Canada than in searching for a nursing position after she finished her nursing course. She said:

...While landed in Canada, I didn't know anybody, so sometimes, you know, I have no network. So, it's really hard to get job. (Participant 5) 
As one of obstacles that immigrant women encounter in finding a job, Participant 1 highlighted:

Lots of people don't know how to (look for a job). Like most of the jobs, $60 \%$ of the job postings you don't see. You have to have people you know, communication, networking and all those things... (Participant 1)

In fact, according to McGill Career and Placement Service (2004), around $80-85 \%$ of jobs are hidden in the job market and are never advertised. The handbook points out that networking is the best way to access these hidden positions. Personally, I also faced absence of networks as a barrier in accessing the labour market. Because I did not have any social networks when I first arrived in the country, I was not aware of the hidden job opportunities in the labour market.

\subsubsection{Lack of Education}

Since the introduction of the point system in 1967 , immigrants in general have a higher level of education than their previous cohorts. Especially since neoliberal restructuring in the $1990 \mathrm{~s}$, the government has put the focus on recruiting those who would immediately be self-reliant and will not rely on state provision (Arat-Koç, 1999, p. 31), the admission of the university (or higher) educated immigrants has increased significantly. The same trend also can be observed among immigrant women. As mentioned earlier, the number of women who apply for immigration as the primary applicant has grown; and women who are sponsored under the Family Class category also have higher educational background.

Under these circumstances, immigrant women who have limited education encounter more difficulties in recent years than in the previous $10-20$ years in the labour market 
participation. Participant 6 shared with me how her work search experiences differed between the late $1990 \mathrm{~s}$, when she first looked for a job and a few years ago, when she planned to rejoin the labour force. As I noted earlier, she used "easy" to illustrate her first job search experience and "very difficult" to describe her second attempt.

Among the seven participants in the study, Participants 5,6 and 7's highest level of education is high school or equivalent. They all noted that limited education is indeed a factor in impeding their labour market integration in Canada. When I asked Participant 6 for what reason did she think that she did not get called for an interview after sending out many resumes, she commented:

I think now they [the employers] are looking for more educated people, you know, like university or college certificated people, but I just finished Grade 12. (Participant 6)

Participant 7 also pointed out that insufficient education has been a big disadvantage in terms of her career options. Throughout the interview, she continuously expressed her eagerness in attending a college, specifically teachers' college, in order for her "dream job" as a school teacher to come true. Participant 4 expressed a different aspect of how education was a barrier for her. She said that when she first came to Canada, she did not know how to use a computer. So although she eagerly wanted a job, she was afraid to be asked whether she had specific skills to contribute to the work place. She recalled:

Every time I looking for a job...(the employers were) asking me computer skills, that time I didn't know anything, I feel very worry how I can take this job, I don't know how to do. (Participant 4) 


\subsubsection{Family Responsibilities and Gender Roles}

Thus far, I have explained how work experience, language, networking and education have impeded immigrant women's access in the labour market. For each participant, however, these barriers have been relevant in different degrees or different ways. For example, regarding "lack of education", Participants 4,6 and 7 found that their limited education has posed a great challenge in finding employment. For Participants 1, 2, 3, and 5, however, since they all had university degrees (Bachelor and Masters), education was not a barrier for them.

Unlike the above factors which varied in their relevance for individual participants, all seven participants in unison indicated family responsibilities as one of the biggest issues they have to consider while planning their career life. A few factors play a role as to why this might be the case. First, all participants in the study have school-aged, or younger children. The study results show that the women's decision on whether they want to work, or what type of job they should work, are based on the situation of their children. Even though the interview was not originally designed to find out whether or not participants had a child, as it was a major issue in job search or career planning, and was therefore brought out frequently by every participant during the interview, I became informed of the number of participants' children.

Second, six out of seven participants were from a South Asian background. Previous research have shown that traditionally, South Asian women are expected to shoulder domestic responsibilities such as child rearing, care for elderly, housework, and passing on cultural tradition (Gupta, 1994; Cassano \& Dunlop, 2005). Apparently, these traditional responsibilities of South Asian women are being practiced even after they migrated to 
Canada. However, in addition to the "traditional responsibilities", South Asian women's career choices are also affected by other factors that are commonly faced by women in general, or other groups of immigrant women such as, absence of affordable childcare and after-school care facilities, as well as lack of family support networks. It is also important to note that some women choose to perform the traditional gender roles voluntarily because they decide that it is the best solution for their family. For example, a woman in Tastsoglou \& Miedema's (2005) study explained that because she was not comfortable leaving her children with strangers (daycare workers), and that she also did not have any extended family members in Canada whom she could seek help from, she decided not to join the labour force in Canada although she had worked as an engineer and university faculty in her home country.

In this section, I will explain how the participants' traditional gender roles as a wife and a mother have had an impact on them selecting their career paths. I will first explain the experience of the six South Asian women and then close the section with the description of the participant from China (participant 5).

Participant 1 described the struggle she had when she was employed, between her work as a payroll accountant and her two children:

I put the kids in the daycare, and coming in (to office) a long time, after reaching my work place, I feel like, even worse... after coming home (from office), I was just like a strange person, I didn't have any energy left for my kids. (Participant 1)

When I asked her whether she planned to look for a job again, she answered that even if she decided to get one, it would be a part-time position because she wanted to stay longer with her kids, "my family experience is more important than mine (my career)" she explained. It 
should be noted that participant 1's husband earned a good income, which she said was enough for her to maintain her expenses. Therefore, she was not pressured to join the labour market for financial purposes.

As a trained engineer back in Pakistan, Participant 2 mentioned how being a mother of two and a married woman in the South Asian community have affected her choice of occupation and her goal as an engineer. When I asked her why she quit one of her previous jobs as a sales staff, she replied that the job was too stressful and it has affected her children indirectly. She said:

I don't want to take pressure. Like I have kids, I have my family. For me, my first priority is my kids, so I just don't want to be stressed out in the job...my son had just started school, and it's also colliding with my husband's [work] schedule, so I left the job. (Participant 2)

And then I asked her whether she was thinking of shifting her career to something that she liked more, she commented:

You know what, like...I have my background is like professional education, I started that because I had a goal in my mind, but you know like when you get married, your decision is like not your individual decision. And as a South Asian woman, like, there are certain things that depend on your husband too... So like, if he is supportive enough, to let you do what you really want, I think that's the biggest thing...Like my husband is like, "if you want to do it, do, do it". But like, you know like, I don't know but for me, it's hard for me like "ok you will do", you know the support should be there. (Participant 2)

Repeatedly throughout the interview, Participant 2 expressed contradictory feelings of eagerness as well as a sense of helplessness in relation to her profession. She was also worried that the longer she stayed at home, the more difficult it would be for her to achieve her dream. 
Reflecting on her own experience, Participant 3 pointed out that South Asian women have no time and opportunity to go out because "most of time they [South Asian women] spend with children". In wrapping up the interview, she concluded:

From my experience, I think, for immigrant women, when they come to new country, (they) have to go outside, LINC class or any kind of program, but don't waste time in the house. Even if you don't get a job, you still have to go out for women's program, LINC class, it will help women, for labour market, Canadian experience. (Participant 3)

The comment from Participant 3 clearly expressed the dilemma that most participants in the study encountered. They all wanted to do something for themselves. Nonetheless, their responsibilities towards their family and children have stopped them from doing so.

Participant 4 mentioned that other than language barrier and lacking work experience, another reason that she gave up looking for work was because of the birth of her child. Participant 6's career choice is also largely affected by her role as a mother. Although her future career goal is to obtain a position in an office environment, she admitted that her current work as a child caregiver is the best choice for her at the time being. She said:

I have to take care of my children also, so I think this is a job good for me, I think...I have three daughters, if I go find a job, then I have to pick up my children from daycare, then I have to cook and clean, so many work. So if I do home daycare, I can look after my kids too... after my children grow up then I will look for another job. (Participant 6)

Likewise, Participant 7 also chose to run a home-based childcare business because for her, "the family is the biggest concern". She said that by working at home, she would be able to take care of her own children at the same time. During the interview, she shared that she was enjoying her current job because "I am at home, I can take care of my own kids, and 
then I am making money at the same time", she said. However, when I asked her whether this is the job that she wanted to do, she replied:

No, I was looking ahead, but because of the family...I wanted to go to the college, at least do something from here (Canada), but here I have to take care of my sons. I couldn't enter college or anything, and that's why I am here (laughter). I wish I could have done more. (Participant 7)

Lastly, Participant 5 described that financial pressures and the potential cost of pursuing her career had forced her to give up being a doctor in Canada. She said "I have to make a living of my family, I have to earn money, I don't live by myself, so...". She explained that she did not want to try to be a doctor because she could not afford the long period the licensing process would take to practice medicine in Canada ${ }^{15}$. She did not want to take the risk because she might end up getting nothing and her time and money spent during training would be wasted. This is an investment that she could not afford because she had a family to support.

The findings of this section confirm the concept of the double-negative effect (Beach \& Worswick, 1993; Boyd, 1984) that immigrant women often have to handle extra stress due to their gender and immigration status. On the one hand, they are expected to take care of the well-being of family members. On the other hand, they are struggling to overcome barriers such as lacking work experience and networking, and limited language proficiency, in order to achieve their career goals. When these barriers and challenges become very significant, the

\footnotetext{
${ }^{15}$ For foreign-trained medical doctors who want to practice medicine in Canada, they must first pass the Medical Council of Canada's Evaluating Examination, and then they are required to be trained at a Canadian university for two years to practice family medicine; they also have to attend training in other specialties for four to five years. On top of these, they also have to pass the "appropriate certification examinations of the College of Family Physicians of Canada or the Royal College of Physicians and Surgeons of Canada (Boyd \& Schellenberg, 2008, p. 1).
} 
expectations of family life become decisive leading women to adopt, at least temporarily, "traditional" roles in the family. Personally, being a mother of two and the wife of a South Asian male, I also often find myself in a dilemma between the family responsibilities and my personal career goal. Because I am "expected" to prioritize my responsibilities as a mother over my personal goals, like some of the women in the study, I look forward to the time my children will be grown up when I can rejoin the labour force.

\subsection{Challenges within the Work Place}

Unlike the experience of accessing the labour market where immigrant women faced great challenges in finding employment, my research indicates that once the women are employed, regardless of whether the job is what they want to do, they are generally satisfied with their position. Nevertheless, throughout the interview, some of the participants did mention challenges that they had to deal with within the work place. The two major challenges that they raised were the working environment and underemployment.

\subsubsection{Working Environment}

Poor conditions in the working environment were a significant issue for Participant 1. She got a payroll accountant position while she was attending a government-funded job search program. However, after she joined the company, she felt that the employer was not "ready to hire a new person". On the first day of work, she was asked to sit at the employer's desk and use the employer's laptop computer; "it was very weird", she said. She also pointed out that the staff in the company showed hostility towards new people in the company and 
that she felt she was not welcomed. She explained that the main reason she was not welcome in the new company was because she was employed during the recession period; the rest of the staff was worried that she (an immigrant) would take away their jobs ${ }^{16}$. For all these reasons, as well as her family obligations to her children, Participant 1 decided to quit work three weeks after joining the company.

Participant 2 stated that her working environment was fine. However, sometimes, she felt uncomfortable because she had to work with a lady from the human resource department whom she described as "very arrogant". She said that the lady always spoke rudely to her. There was one incident when the Participant 2 was sitting at a place that was designated by her supervisor. The lady came and shouted at her "why are you sitting at that place? I told you [to sit] somewhere [else]". In describing her feelings at that moment, she said:

I didn't carry on my shift that day. I was feeling very humiliated. Then I spoke to my supervisor and then I came back home. Nobody has ever spoken to me like that. (Participant 2)

When I asked Participant 2 whether the lady who scolded her had also showed the same attitude to other staff in the company, or she was the only target, she replied that the lady was one of those people who are "extra kind to boys but rude to girls". Although Participant 2 did not explicitly associate her experience with any form of discrimination, I would argue that she was in fact discriminated against in the workplace due to her gender and race.

Being employed in three different facilities (nursing home, hospital and retirement house), Participant 5 described her work places in the nursing home and the hospital as

\footnotetext{
${ }^{16}$ In fact, immigrants have historically been perceived by Canadians as an economic threat. A study conducted in the 1970s indicates that more than half of Canadians believed that immigrants would increase the unemployment rate in the country. In the $1990 \mathrm{~s}$, another study reveals that Canadians were concerned that "immigrants will often take jobs away from Canadians" (Esses et al., 1999, p.214)
} 
"stressful". Especially in the nursing home, she said that she had to manage 28 clients all by herself, not only did she have to take care of the clients, she was also expected to "call doctor", "transfer order" and handle complaints from the clients' families. She said:

Our client's age is from $80-100$. Someone is already 100 , but the family wants them to living longer, actually you know, 100 years old cannot similar to 20 years old, they are lack of energy, but the family want to give them more energy, they [the family members] ask us to force them [the clients], but we cannot force them...everyone wants to get $100 \%$ care, but they cannot. So that's why this is the biggest issue in nursing home. (Participant 5)

In regards of working with other staff, she mentioned that in the nursing home, she had to manage two to three personal support workers, and she had to cooperate with other nurses in the hospital. Some of them, in her opinion, were "easy to get going"; however, some were "very hard to get along with".

\subsubsection{Underemployment}

The research conducted by Beach \& Worswick's (1993) found that the doublenegative effect of gender and country of origin is more prominent among highly educated immigrant women in the labour market participation. My research also had similar findings. It shows that immigrant women who had obtained a Bachelor Degree or higher, encountered more obstacles in finding employment that were relevant to their education and previous work experience. For example, Participant 5 had given up becoming a doctor in Canada. Instead, she chose to be a nurse because of her financial obligation to her family. Although in the interview she said that she was happy with the pay that she is earning, and that she is looking for a permanent position as a nurse, she sent out a strong signal that she is not 
actually doing what she really wants to do. I also felt that she had lost her passion in her career when I asked her to describe her dream job. She said:

Dream job? In Canada? Hahahahaha (laughter).

Then she continued calmly, with a very low tone:

Actually I have no dream job, I chose this job is because I have to, I have to work, I have to make a living. I have to face the reality. I never think about to be a doctor because you know I think that is not reality, that's a dream (bitter laughter). (Participant 5)

Knowing that it was impossible for her to become a doctor her in Canada (because she had chosen a different occupation), Participant 5 had set a different goal in her life. She told me that she hoped to get a full time nursing position to replace her current three part-time positions. She was confident that she could find such a position in the near future.

Participant 2 was trained as an engineer in her home country. However, the only jobs that she could find in Canada were in sales or customer service-related positions. Although she hoped that she could find a job in her field one day, she also understood that she needed to accept and work in the positions that she could find at the time being. Therefore, even though she said that she was generally happy with service jobs, and that she also looked forward to rejoining the labour market (customer service) three days after the interview, she did not consider these jobs as part of her career. Zaman (2008) states in her research that because of the patriarchal ideology that dominates among South and South East Asian families, men are usually the ones who get retrained or reeducated after migration. On the other side, women as wives and dependents are involved in low paid, part-time and flexible jobs. Likewise, due to family responsibilities and lack of support from her husband in 
planning for her career, Participant 2 had no choice but to engage in feminized occupations. In fact, she treats these jobs as tools to earn money so that she could be financially independent and further study or upgrade herself, in order for her to find a job that suits her qualification in the future. 


\section{CONCLUSION AND RECOMMENDATIONS}

With the participation of seven immigrant women living in the Flemingdon Park area, this paper has explored the barriers and challenges that immigrant women face in accessing the labour market, as well as within the labour market. The findings confirm some of the barriers and challenges that were identified in the literature review such as language barrier, lack of work experience and gender. Although race was identified as a major barrier for immigrant women of visible minority in previous research, it has not been identified by the seven participants in my research as a major barrier or challenge, despite the fact that all seven participants are visible minorities. As I argued earlier, this finding does not necessarily mean that the participants in the study have not faced any racial discrimination in their labour market experiences. They might not have pointed it out because the subtle ways in which racism often works either makes it invisible to people or it makes individuals feel it is unworthy of mentioning as a real problem.

The study results contradict human capital theory which assumes that investment spent on education will be returned in the labour market. Immigrant women's investments in education abroad (especially for those who spent money on higher education) do not benefit them financially in the new country. They are found segregated in the part-time and low pay secondary sector jobs such as customer service and sales positions. These secondary jobs also do not offer any benefits and chances for promotion. Moreover, there is also no indication that the chances of immigrant women getting employed in the primary sector will improve with the increase of their stay in the country. As a result, the findings suggest that labour market segmentation theory is indeed a more appropriate theory in explaining the nature of labour market participation of immigrant women in the Canadian labour market. 
The findings also reveal that despite all the obstacles that the immigrant women in the study face, they are not giving up in reaching their dream jobs in the future. In reaction to the barriers they face, they have developed some strategies. Their main strategies include, but are not limited to, first, involving in volunteer activities to gain work experience and to increase their social network, as well as to improve their conversational skills; second, attending language classes to improve their language skills; and third, taking jobs that they are able to carry out at the time being. Through the third strategy they hope to save some money and be financially independent, so that they can pursue higher education or gain Canadian credential when their children grow up.

Even though immigrant women take initiatives and actively develop strategies in achieving their goals, it needs to be remembered that integration of immigrants is supposed to be a "two-way street" where both Canadian society and the state, on the one hand, and immigrants, on the other, are expected to take responsibility (Biles et al., 2008, p.4). I argue that the economic integration of immigrant women is not a sole responsibility of immigrant women themselves; Canadian government and citizens should also provide supports for immigrant women to overcome barriers in order for them to have a smooth transition into the Canadian labour market. In order to alieviate the difficulties that immigrant women face in integrating successfully into the labour market, I propose that the government should increase the funding to improve the services on the following facilities and programs:

First, there should be an increase in the number of affordable and reliable child care facilities. As this study has revealed, "children" are the biggest concern that immigrant women (who have kids) face while they try to land a job. Since the neo-liberal restructuring of the $1990 \mathrm{~s}$, because of the drastic cuts in social spending, many government-funded 
childcare programs have been privatized. This restructuring has created a stressful situation for immigrant women. On the one hand, they desperately need a job to support the family or to be financially independent from their husband. On the other hand, they face constraints because they cannot afford the high cost of childcare fees. Therefore, creating more affordable and safe childcare environment will definitely increase the economic well-being of immigrant women.

Second, more government-funded employment programs should be held. Participant 1 successfully found a position after she enrolled in an employment program. Prior to the program, although she has already obtained the relevant certification in Canada, she was not able to get a job. Her experience demonstrates that employment programs are indeed proven to be helpful to many immigrants. Immigrant women are considered to be more in need of these programs because of their relative social isolation. Through the programs, not only can they learn about the labour market opportunities in the country, but they also can increase their networking skills, which has been identified as one of the major obstacles in this study.

Last but not least, a language training program with a more holistic approach should be available to all (including new and naturalized) immigrant. The current Language Instruction for Newcomers to Canada program is only available to immigrants who have recently arrived and have not yet acquired Canadian citizenship. Immigrants who have already naturalized and obtained a Canadian citizenship are not allowed to access the LINC program. Although there are other language training programs such as ESL available to them, some of these programs are not free. More importantly, the ESL ${ }^{17}$ program does not provide

\footnotetext{
${ }^{17}$ Immigrant women are often in a dilemma between the need for language training and naturalization due to the lack of childminding service in the ESL program (Gormley \& Gill, 2007).
} 
child care services as the LINC does. Therefore, naturalized immigrants who require child minding often are not able to attain the necessary language training. Naturalized immigrant women are especially disadvantageous due to this restriction, because they are often the primary care givers of the children and may therefore be delayed after their arrival in Canada in attending language courses (Gormley \& Gill, 2007).

Aiming to explore the barriers and challenges immigrant women face in the Canadian labour market, this study has been limited, because of the time constraints, as it could only focus on the immigrant women in the Flemingdon neighbourhood in Toronto. What would significantly improve understanding of the barriers and challenges that immigrant women face in their labour market participation would be, more locally based ethnographic research, as well as a larger scale research that involves immigrant women from different locations and from various ethnic backgrounds.

In conclusion, it can be argued that even though economic integration of immigrant women in the new country is challenging, immigrant women are able to develop several strategies in overcoming these barriers. However, their ability to successfully develop and pursue effective strategies is limited due to the extra burdens and responsibilities they carry as mothers and wives. Therefore, the government's support in this area is crucial and essential for the success of these women. 


\section{REFERENCES}

Anker, R. (1998). Gender and Jobs: Sex Segregation of Occupations in the World. Geneva: International Labour Organization.

Arat-Koç, S. (1999). Neo-liberalism, State Restructuring and Immigration: Changes in Canadian Politics in the 1990s. Journal of Canadian Studies, 34(2), 31-56.

Arat-Koç, S. (2006). From 'Mothers of the Nation' to Migrant Workers: Immigration Policies and Domestic Workers in Canadian History. In M. Gleason and A. Perry (Eds.), RethinkingCanada: The Promise of Women's History (pp. 195-209). Oxford University Press.

Arnopoulos, S. (1979). Problems of Immigrant Women in Canadian Labour Force. Ottawa: The Canadian Advisory Council on the Status of Women.

Ashton, D., \& Green, F. (1996). Education, Training, and the Global Economy. Cheltenham, UK: Edward Elgar Publishing Limited.

Bauder, H. (2003). "Brain Abuse", or the Devaluation of Immigrant Labour in Canada. Antipode, 35(4), 699-717

Bauder, H. (2005). Habitus, Rules of the Labour Market and Employment Strategies of Immigrants in Vancouver, Canada. Social \& Cultural Geography, 6(1), 81-97.

Beach, C. M., \& Worswick, C. (1993). Is there a Double-Negative Effect on the Earnings of Immigrant Women? Canadian Public Policy, 19(1), 36-53.

Biles, J., Burstein, M., \& Frideres, J. (2008). Immigration and Integration in Canada: In the Twenty-first Century. Kingston: School of Policy Studies, Queen's University.

Bourdieu, P. (1977). Outline of a Theory of Practice. Cambridge: Cambridge University Press.

Boyd, M. (1984). At a Disadvantage: The Occupational Attainments of Foreign Born Women in Canada. International Migration Review, 18(4), 1091-1119.

Boyd, M. (2009). Immigration Trends, Language Skills and the Labour Market Integration of Recent Immigrants. Retrieved July 30, 2010 from http:/canada.metropolis.net/events/metropolis_presents/LanguageSeminar/Presentations/ Boyd_Lang_LM_paper_e.pdf

Boyd, M., \& Schellenberg, G. (2008). Re-accrediation and the Occupations of Immigrant Doctors and Engineers. Retrieved July 31, 2010 from http://www.statcan.gc.ca/pub/11-008-x/2007004/10312-eng.htm 
Buzdugan, R., \& Halli, S. S. (2009). Labor Market Experiences of Canadian Immigrants with Focus on Foreign Education and Experience. International Migration Review, 43(2), 366-386.

Cassano, R., \& Dunlop, J. M. (2005). Participatory Action Research with South Asian Immigrant Women: A Canadian example. Retrieved July 22, 2010 from $\mathrm{http} / / /$ www.uwindsor.ca/criticalsocialwork/participatory-action-research-with-southasian-immigrant-women-a-canadian-example

Cheng, S. A. (1999). Labour Migration and International Sexual Division of Labor: A Feminist Perspective. In G. A. Kelson and D. L. DeLaet (Eds.), Gender and Immigration (pp. 38-58). Lodon: Macmillan Press.

Citizenship and Immigration Canada (2009). Facts and Figures 2008 - Immigration Overview: Permanent and Temporary Residents. Retrieved July 20, 2010 from http://www.cic.gc.ca/english/resources/statistics/facts2008/permanent/index.asp

Citizenship and Immigration Canada (2009). Applying as a Skilled Worker. Retrieved July 04, 2010 from http:/www.cic.gc.ca/english/information/applications/skilled.asp

City of Toronto (2007). Flemingdon Park (44) Social Profile \#1 - Neighbourhoods Age and Gender. Retrieved July 10, 2010 from http://www.toronto.ca/demographics/cns_profiles/2006/pdf1/cpa44.pdf

Creese,G., \& Kambere, E. N. (2002). "What Colour is Your English?" Vancouver Centre of Excellence Working Paper Series, No.20.

Creswell, J. W. (2007). Qualitative Inquiry \& Research Design: Choosing Among Five Approaches (2nd ed.). Thousand Oaks: Sage Publications.

Creswell, J. W. (2009). Research Design: Qualitative, Quantitative, and Mixed Methods Approaches (3rded.). Thousand Oaks: Sage Publications.

Esses, V. M., Jackson, L. M., Nolan, J. M., \& Armstrong, T. L. (1999). Economic Threat and Attitudes toward Immigrants. In S.S Halli and L. Driedger (Eds.), Immigrant Canada: Demographic, Economic, and Social Challenges (pp. 212-229). Toronto: University of Toronto Press.

Fichtenbaum, R. (2006). Labour Market Segmentation and Union Wage Gaps. Review of Social Economy, 64(3). 387-420.

Gabriel, C. (2004). A Question of Skills: Gender, Migration Policy and the Global Political Economy. In K. Jijl, L. Assassi and D. Wigen (Eds.), Global Regulation: Managing Crises After the Imperial Turn (pp. 162-176). Palgrave Macmillan. 
Galabuzi, G. E. (2004). Racializing the Division of Labour: Neoliberal Restructuring and the Economic Segregation of Canada's Racialized Groups. In J. Stanford and L. Vosko (Eds.), Challenging the Market: The Struggle to Regulate Work and Income (pp. 175204). Montréal: McGill-Queen's University Press.

Galabuzi, G. E. (2006). Canada's Economic Apartheid: The Social Exclusion of Racialized Groups in the New Century. Toronto: Canadian Scholars' Press Inc.

Girard, E. R., \& Bauder, H. (2007). Assimilation and Exclusion of Foreign Trained Engineers in Canada: Inside a Professional Regulatory Organization. Antipode, 39(1), $35-53$.

Gormley, L., \& Gill, B. S. (2007). A Study of Language Learner Needs and Barriers to Accessing Language Instruction for Newcomers to Canada (LINC) Programs in Hamilton, Ontario. Hamilton: Settlement and Integration Services Organization.

Grady, P. (2009). The Impact of Immigration on Canada's Labour Market. Retrieved July 06, 2010 from http://globaleconomics.ca/ImpactofImmigrationonCanadasLabourMarket.pdf

Grewal, S., Bottorff, J. L., \& Hilton, B. A. (2005). The Influence of Family on Immigrant South Asian Women's Health. Journal of Family Nursing, 11(3), 242-263.

Gupta, T. D. (1994). Political Economy of Gender, Race, and Class: Looking at South Asian Immigrant Women in Canada. Canadian Ethnic Studies, 26(1), 59-73.

Hiebert, D. (1999). Local Geographies of Labor Market Segmentation: Montreal, Toronto, and Vancouver, 1991. Economic Geography, 75(4), 339-369.

Hirsch, E. (1980). Dual Labor Market Theory: A Sociological Critique. Sociological Inquiry, 50(2), 133-145.

Holloway, I. (1997). Basic Concepts for Qualitative Research. London: Blackwell Science Ltd.

Human Recourses and Skills Development Canada (2007). A Study of Poverty and Working Poverty Among Recent Immigrants to Canada. Retrieved July 06, 2010 from http://www.hrsdc.gc.ca/eng/publications_resources/research/categories/inclusion/200 7/sp_680_05_07_e/page04.shtml

Hyslop-Margison, E. J., \& Sears, A. (2006). Neo-liberalism, Globalization and Human Capital Learning: Reclaiming Education for Democratic Citizenship. Dordrecht: Springer. 
Ilcan, S., Oliver, M., \& O'connor, D. (2007). Spaces of Governance: Gender and Public Sector Restructuring in Canada. Gender, Place \& Culture: A Journal of Feminist Geography, 14(1), 75-92.

Jenkins, S. (2004). Gender, Place, and the Labour Market. Aldershot: Ashgate

Li, P. (2003). Destination Canada: Immigration Debates and Issues. Don Mills: Oxford University Press.

Man, G. (2002). Globalization and the Erosion of the Welfare State: Effects on Chinese Immigrant Women. Canadian Woman Studies, 21/22(4/1), 26-32.

Man, G. (2004). Gender, Work and Migration: Deskilling Chinese Immigrant Women in Canada. Women's Studies International Forum, 27(2), 135-148.

McGill University Career \& Placement Service (2004). CAPS job search handbook. Retrieved August 15, 2010 from http://caps.mcgill.ca/jobsearchbook/CAPS_job_search_handbook.pdf

Miedema, B., \& Tastsoglou, E. (2000). "But Where Are You From, Originally?": Immigrant Women and Integration in the Maritimes. Atlantis: A Women's Studies Journal, 24(2), $82-91$.

Mitlacher, L. W. (2005). Temporary Agency Work, the Changing Employment Relationship and its Impact on Human Research Management. In W. Nienhuser (Eds.), Flexible Work-Atypical Work - Precarious Work? (pp. 371-388) Mering: Management Revue

Mojab, S. (1999). De-skilling Immigrant Women. Canadian Women Studies, 19(3), 123-128.

Moro, A. (n.d.). Statistical Discrimination. Retrieved August 08, 2010 from http://www.andreamoro.net/perm/papers/palgrave-statistical-discrimination.pdf

Moro, A., \& Norman, P. (2003). Empirical Implications of Statistical Discrimination on the Returns to Measures of Skill. Annales d' Economie et de Statistique, 71(72), 399417.

Murty, M. (1998). Healthy Living for Immigrant Women: A Health Education Community Outreach Program. Canadian Mfedical Association Journal, 159(4), 385-387.

Nativel, C. (2004). Economic Transition, Unemployment and Active Labour Market Policy: Lessons and Perspectives from the East German Bundeslander. Birmingham: The University of Birmingham Press.

Ng, R. (1990). Immigrant Women: The Construction of a Labour Market Category. Canadian Journal of Women and the Law, $f(1), 96-112$. 
Ng, R. (1996). The Politics of Community Services: Immigrant Women, Class and the State. Nova Scotia: Fernwood Publishing.

Ontario Council of Agencies Serving Immigrants (2006). Bill 124-Fair Access to Regulated Professions Act. Retrieved July 25, 2010 from http://www.ocasi.org/downloads/OCASI_Comments_Bill124.pdf

Ontario.ca (2009). McGuinty Government Introduces Legislation to Break Down Barriers for Newcomers. Retrieved July 31, 2010 from http://news.ontario.ca/archive/en/2006/06/08/c768997cd-27996-tpl.html

Oreopoulos, P. (2009). Why do Skilled Immigrants Struggle in the Labor Market? A Field Experiment with Six Thousand Resumes. Retrieved July 09, 2010 from http://www.cbc.ca/bc/news/bc-090520-ubc-study-names-jobs.pdf

Peterson, J., \& Lewis, M. (1999). The Elgar Companion to Feminist Economics. UK: Edward Elgar Publishing Limited.

Polit, D. F., \& Beck, T. (2008). Nursing Research: Generating and Assessing Evidence for Nursing Practice $\left(8^{\text {th }}\right.$ ed.). Philadelphia: Lippincott Williams \& Wilkins.

Preston, V., \& Giles, W. (2004). Employment Experiences of Highly Skilled Immigrant Women: Where Are They in the Labour Market? Retrieved July 10, 2010 from http://www.genderwork.ca/conference/Preston-Giles_edited_final.pdf

Reitz, J. G. (2001). Immigrant Skill Utilization in the Canadian Labour Market: Implications of Human Capital Research. Journal of International Migration and Integration, 2(3), 347-348.

Salaff, J., \& Greve, A. (2006). Why do Skilled Women and Men Emigrating from China to Canada Get Bad Jobs? In E. Tastsoglou and A. Dobrowolsky (Eds.), Women, Migration and Citizenship (pp. 85-106). Aldershot, Hampshire: Ashgate.

Shamsuddin, A. F. M. (1997). The Double-negative Effect on the Earning of Foreign-born Females in Canada. Vancouver Centre of Excellence Working Paper Series, No.04.

Shan, H. (2009). Shaping the Re-training and Re-education Experiences of Immigrant Women: The Credential and Certificate Regime in Canada. International Journal of Lifelong Education, 28(3), 353-369.

Sorensen, M. (1995). The Match between Education and Occupation for Immigrant Women in Canada. Canadian Ethnic Studies, 27(1), 48-66.

Statistics Canada (2006). Women in Canada 2005: A Gender-based Statistical Report. Ottawa: Statistics Canada. 
Statistics Canada (2010). Census Tract (CT) Profiles, 2006 Census. Retrieved July 05, 2010 from http://www12.statcan.ca/census-recensement/2006/dp-pd/prof/92597/index.cfm?lang=E

Stasiulis, D. K., \& Bakan, A. B. (2005). Negotiating Citizenship: Migrant Women in Canada and the Global System. Toronto: University of Toronto Press.

Tastsoglou, E., \& Preston, V. (2005). Gender, Immigration and Labour Market Integration: Where We Are and What We Still Need to Know. Atlantis 30(1), 46-59.

Tastsoglou, E., \& Miedema, B. (2005). "Working Much Harder and Always Having to Prove Yourself": Immigrant Women's Labor Force Experiences in the Canadian Maritimes. In V. Demos and M. Segal (eds.), Gender Realities: Local and Global (Advances in Gender Research, Volume 9) (pp. 201-233). Emerald Group Publishing Limited.

Teelucksingh, C., \& Galabuzi, G. E. (2007). Working Precariously: The Impact of Race and Immigrant Status on Employment Opportunities and Outcomes in Canada. In T. D. Gupta, C. E. James, R. C. Maaka, G. E. Galabuzi and C. Andersen (Eds.), Race and Racialization Essential Readings (pp. 202-208). Toronto: Canadian Scholars' Press Inc.

Taylor, M. C. (2005). Interviewing. In I. Holloway (Eds.), Qualitative Research in Health Care (pp. 39-55). Berkshire, England: Open University Press.

Toronto Neighbourhood (n.d.). Flemingdon Park Overview. Retrieved July 05, 2010 from http://toneighbourhoods.ca/north-york/flemingdon-park/overview/

Tufts, S., Damsbaek, N., Phan, M., Kelly, P., Lemoine, M., Lo, L. et al. (2010). Does Selfreported English and French Speaking Ability Affect Labour Market Outcomes for Immigrant? Toronto Immigrant Employment Data Initiative (TIEDI) Analytical Report 6. Retrieved August 03, 2010 from http://www.yorku.ca/tiedi/doc/AnalyticalReport6.pdf

Yates, C., \& Leach, B. (2007). Industrial Work in a Post-industrial Age. In V. Shalla $\&$ W. Clement (Eds.), Work in Tumultuous Times: Critical Perspective (pp. 163-191). Canada: McGill-Queen's University Press.

Zaman, H. (2007). Neo-liberal Policies and Immigrant Women in Canada. In S. Lee and S. McBride (Eds.), Neo-liberalism, State Power and Global Governance (pp. 145-156). Dordrecht: Springer.

Zaman, H. (2008). Immigrant Women and Accreditation in Canada. Thirdspace: A Journal of Feminist Theory \& Culture, 7(2), 85-89. 


\section{APPENDIX A \\ Interview Question}

\section{Demographic Questionnaire}

The purpose of the interview is to understand obstacles that immigrant women face while accessing the labour market.

You can opt not to answer any specific question as you wish.

\section{Background information}

1) For how long have you been living in Canada?

$\square$ Less than 5 years $\square 5$-10 years $\square$ 10-15 years

2) How old are you?

$\square$ 18-30 $\square 31-40 \quad \square$ 41-50 $\square$ 51-65

3) What is the highest education you have attainted?

$\square$ Less than high school $\quad \square$ High School or equivalent

$\square$ College or University $\quad \square$ University post-graduate

4) Under what category did you come to Canada?

$\square$ Independent Class $\square$ Family Class $\square$ Refugee

5) Have you ever attended school in Canada?

$\square$ Yes $>$ What kind of study?___ For how long?___ $\quad \square$ No

6) Have you worked before coming to Canada? (If yes, what kind of job?)

Yes $\rightarrow$ What kind of job?

No

7) Have you ever worked in Canada? (If yes, what kind of job?)

$\square$ Yes $>$ What kind of job?

No

8) Are you working currently? (If yes, what kind of job?)

$\square$ Yes $>$ What kind of job? 
Questions related to labour market. In this section, interview questions will be separated into three different parts depending on which category the interviewee belongs:

\section{A) Women who worked in Canada before but are not working now}

9) Do you think your background (education and previous work experience) had helped you when you looked for a job?

10) Was it easy for you to find the job?

11) Did you face any barrier when you were looking for a job? (If yes, please describe)

12) What are the challenges you have faced in the workplace?

13) Why did you stop working?

14) Are you thinking of looking for a job again? (If not, why?)

15) What do you think is the most challenging part for immigrant women to access the labour market in Canada?

16) Describe your dream job

17) Do you think there is chance for you to get your dream job in the future and why?

B) Women who tried to look for work but unsuccessful

9) Do you think your educational background had helped you when you looked for a job?

10) What barriers did you face when you were looking for a job?

11) Why did you stop looking for a job?

12) Are you thinking of looking for a job again? (if not, why?)

13) What do you think is the most challenging part for immigrant women to access the labour market in Canada?

14) Describe your dream job.

15) Do you think there is chance for you to get your dream job in the future and why?

C) Women who are working now

9) Do you think your background (education and previous work experience) had helped you when you looked for a job?

10) Was it easy for you to find the job?

11) Did you face any barrier when you were looking for a job? (If yes, please describe)

12) Are you hired in a job that you would want to do? (If not, what type of job would you like to do)

13) How do you feel about your current job?

14) Are you happy with the salary that you get?

15) Discuss your current work experience.

16) Are you thinking of looking for another job and why?

17) What do you think is the most challenging part for immigrant women to access the labour market in Canada?

18) Describe your dream job.

19) Do you think there is chance for you to get your dream job in the future and why? 